\title{
EFFECT OF REPLACING MINERAL NITROGEN BY ORGANIC MANURES UNDER DIFFERENT IRRIGATION REGIMES ON: B.PRODUCTIVITY AND WATER USE EFFICIENCY OF "ANNA" APPLE TREES \\ Mikhael, G.B.Y.* and Manal A. Aziz** \\ * Deciduous Fruit Trees Res. Dept., Hort. Res. Inst., ARC, Giza, Egypt. \\ ** Soil, Water and Environ. Res. Inst., ARC, Giza, Egypt.
}

\begin{abstract}
This study was conducted through three successive seasons of 2011, 2012 and 2013 to investigate the effect of three irrigation regimes at $70 \%, 50 \%$ and $30 \%$ of available soil water and seven fertilization treatments include replacing $50 \%$, $75 \%$ and $100 \%$ of mineral nitrogen by cattle or chicken organic manure comparing to $100 \%$ mineral fertilizer and their interaction on productivity, fruit quality and some water relations of "Anna" apple trees budded on Malus rootstock grown on clay soil at Tanta district, El-Gharbia Governorate. Results were only taken in 2012 and 2013 season.

The obtained results could be summarized as follows:

Yield of "Anna" apple tree as fruits number and their weight $(\mathrm{kg})$ as well as total yield (ton/fed) were gradually increased by increasing irrigation rate from $30 \%$ to $70 \%$ of available soil water due to the increase of fruit set $\%$ and reduced preharvest fruit drop \% in both seasons.

- Application of $50 \%$ chicken or cattle manure $+50 \%$ mineral fertilizer $\left(\mathrm{F}_{2} \& \mathrm{~F}_{5}\right)$ produced maximum tree yield as fruits number and weight $(\mathrm{kg})$ also total yield ton/fed. followed by $100 \%$ mineral. While, minimum yield correlated to that fertilized with $100 \%$ cattle or chicken manures in the two seasons of study .

- Highest yield kg/tree and ton/fed. were produced when "Anna" apple trees grown under high or moderate irrigation regimes $\left(70\right.$ or $50 \% \mathrm{AW}$ ) and received $50 \%$ cattle or chicken manure $+50 \%$ mineral $\mathrm{N}$ fertilizer in $\left(\mathrm{I}_{1} \times \mathrm{F}_{2}\right),\left(\mathrm{I}_{1} \times \mathrm{F}_{5}\right),\left(\mathrm{I}_{2} \times \mathrm{F}_{2}\right)$ and/or $\left(\mathrm{I}_{2} \times \mathrm{F}_{5}\right)$ combination treatment without any significant differences among them while, trees subjected to severe water stress $(30 \% \mathrm{AW})$ and fertilized by $100 \%$ cattle or chicken manure in $\left(\mathrm{I}_{3} \times \mathrm{F}_{4}\right)$ or $\left(\mathrm{I}_{3} \times \mathrm{F}_{7}\right)$ treatment gave the least significant values in both seasons.

- Increasing irrigation level resulted in a significant increase of fruit weight, volume, dimensions but reduce fruit firmness and TSS and anthocyanin contents. Meanwhile, nitrate and nitrite contents insignificantly affected with irrigation regime.

The heaviest and largest fruits were recorded by adding nitrogen as 50\% cattle or chicken manure $+50 \%$ mineral fertilizer followed by applying mineral fertilizer alone while, the lightest and smallest fruits were produced by using organic manure alone. Moreover, increasing the rate of organic manure in fertilization program significantly improved the chemical properties of apple fruit in term of increased total soluble solids (TSS) and anthocyanin contents but reduced nitrate and nitrite contents.

- Data of both seasons revealed that, the interaction ( $\mathrm{I} \times \mathrm{F}$ ) was significant and maximum fruit weight, volume and dimensions belonged to $\left(\mathrm{I}_{1} \times \mathrm{F}_{2}\right),\left(\mathrm{I}_{1} \times \mathrm{F}_{5}\right),\left(\mathrm{I}_{2} \times \mathrm{F}_{2}\right)$ or $\left(\mathrm{I}_{2} \times \mathrm{F}_{5}\right)$ combination treatments without significant difference among them. While, the least values obtained by $\left(\mathrm{I}_{3} \times \mathrm{F}_{4}\right)$ or $\left(\mathrm{I}_{3} \times \mathrm{F}_{7}\right)$ treatment. In addition, red color\% and anthocyanin content of apple fruit skin were significantly highest under $\left(I_{2} \times F_{2}\right)$ or $\left(I_{2} \times F_{5}\right)$ treatment. Meanwhile, the control treatment $\left(I_{1} \times F_{1}\right)$ obtained the least values.

- Minimum values of seasonal water consecutive use, $\mathrm{m}^{3}(\mathrm{CU})$ recorded with deficit irrigation rate. On the contrary, the maximum values belonged to high irrigation level. Furthermore, the highest significant values of water use efficiency (WUE) and productivity of irrigation water (PIW) $\mathrm{kg} / \mathrm{m}^{3}$ obtained when tree irrigated at moderate irrigation regime (50\% AW).

- Trees fertilized with $100 \%$ cattle or chicken manure consumed the least values of water. Meanwhile, tree irrigated at 50\% AW gave the highest significant values of water use efficiency and productivity of irrigation water. However, the interaction ( $\mathrm{I} x$ F) was significant in both seasons and the highest values of WUE and Piw were recorded by $\left(I_{2} \times F_{2}\right)$ or $\left(I_{2} \times F_{5}\right)$.

Thus, this study recommended "Anna" apple growers to irrigate their trees at $50 \%$ available water and apply $50 \%$ cattle or chicken manure plus $50 \%$ mineral $\mathrm{N}$ fertilizer in $\left(\mathrm{I}_{2} \times \mathrm{F}_{2}\right)$ or $\left(\mathrm{I}_{2} \times \mathrm{F}_{5}\right)$ combination treatment which consider the best one for producing maximum yield with good quality, beside, reducing water consumptive use and increasing water use efficiency and productivity of irrigation water.
\end{abstract}

\section{INTRODUCTION}

"Anna" apple (Malus domestica, Barkh) is considered one of the leading apple cultivars in Egypt, being of low chilling requirements. It needs chilling about $300-350$ hrs below $7.2^{\circ} \mathrm{C}$ to break their bud dormancy (Zayan and Morsy, 1989). The cultivated area of "Anna" apple cultivar is being increased rapidly especially during the last three decades to reach 53443 feddan in 2013 which produced 546164 ton according to FAO (2013).

In Egypt, although the quantity of irrigation water is available, the ideal use of this water is essential. This minimizing water use not only reduced production cost but also help to meet the environmental regulation due to reduce the leaching of nutrients into ground water (Hanks, 1983). Soil moisture content is one of the main factors that most likely affect fruit production and fruit quality (Abd El-Samad et al., 2006; Fallahi et al., 2010; Mohuram and Zeen El-Deen, 2011 and Wang et al., 2014).

Increasing moisture stress reduced the actual consumptive use and productivity of "Anna" apple trees (El-Gendy and Abd El-Messeih, 2002 and Mikhael and Mady, 2007). Moreover, increasing irrigation rate (IR) from 11.76 to $17.64 \mathrm{~m}^{3}$ water/tree/year significantly increased yield and improved fruit quality and water use efficiency of pear trees (Fathi, 1999). 
Fertilization, especially nitrogen is one of an important management tools for increasing crop yield. The efficiency of nitrogen fertilizer under field and surface irrigation conditions, rarely exceeds $50 \%$ and is usually ranging between 30 and 40\% (Sahrawat, 1979). Such low efficiency may be due to losses of nitrogen from soils as nitrate and nitrite by leaching or as $\mathrm{N}$ gas through nitrate reduction by volatilization (Goring, 1962), which causing many problems such as nitrate and nitrite pollution of ground water and environment. Moreover, they alter the composition of vegetables, fruits and root crops and decrease their content of vitamins, minerals and other useful compounds, beside harmful residues that remain in food pose threats to health (Bogatyre, 2000). Thus organic fertilization is used as partially or completely substitute for mineral $\mathrm{N}$ fertilization for fruit crops to avoid pollution of the environment and produce a safe food.

Application of organic manures as $\mathrm{N}$ source has been considered as a best management because organic $\mathrm{N}$ is more gradually released than water soluble in organic $\mathrm{N}$ fertilizers. In addition, organic manures has numerous merits such as reducing soil $\mathrm{pH}$ and increasing the availability of all nutrients, reducing soil salinity as well as enhancing soil fertility, water retention, soil organic matter, soil cation exchange, biological activity, formation of natural hormones and antibiotics (Nijjar, 1985).

Previous studies emphasized all different benefits of using the suitable $\mathrm{N}$ through inorganic and organic sources rather than using mineral $\mathrm{N}$ fertilization alone in enhancing yield and fruit quality of various fruit crops (Barakat et al., 2007; El-Sehrawy, 2008; Gad El-Kareem, 2009; Ahmed et al., 2012; Salama et al., 2012 and Zuoping et al., 2014).

The present investigation was planned to study the possible effects of three irrigation regimes and replacing mineral $\mathrm{N}$ fertilizer by using two organic $\mathrm{N}$ fertilizers namely cattle and chicken manures on yield, fruit quality and water use efficiency of "Anna" apple trees grown on clay soil.

\section{MATERIALS AND METHODS}

The present study was planned during three progressive seasons of 2011, 2012 and 2013 on 8 years old "Anna" apple trees budded on Malus rootstock to determine the effect of irrigation regimes and replacing mineral nitrogen fertilizer by cattle or chicken manures as an organic fertilization on productivity, fruit quality and water use efficiency of "Anna" apple trees. Results were taken in both 2012 and 2013 seasons. The trees were grown on clay soil at a commercial orchard in Khalwat Rishah village, North Tanta District, belonging to El-Gharbia Governorate, Egypt. The experimental site represents the circumstance and conditions of North Middle Nile Delta region. Agrometerological data of Sakha Weather Station, RRTC, ARC during the two seasons of 2012 and 2013 are presented in Table (1).

Table (1): Mean of some meteorological data for North Middle Delta area during the two growing seasons of 2012 and 2013.

\begin{tabular}{|c|c|c|c|c|c|c|c|c|c|c|c|c|c|c|}
\hline \multirow{3}{*}{ Month } & \multicolumn{7}{|c|}{2012 season } & \multicolumn{7}{|c|}{2013 season } \\
\hline & \multicolumn{2}{|c|}{$\begin{array}{c}\text { Air } \\
\text { temperature } \\
{ }^{\circ} \mathrm{C}\end{array}$} & \multicolumn{2}{|c|}{ RH\% } & \multirow{2}{*}{$\begin{array}{c}\text { Wind } \\
\text { speed } \\
(\mathrm{km} / \text { day })\end{array}$} & \multirow{2}{*}{$\begin{array}{c}\text { Pan } \\
\text { evap., } \\
\text { mm/day }\end{array}$} & \multirow{2}{*}{$\begin{array}{l}\text { Rain, } \\
\text { mm/ } \\
\text { month }\end{array}$} & \multicolumn{2}{|c|}{$\begin{array}{c}\text { Air } \\
\text { temperature } \\
{ }^{\circ} \mathrm{C}\end{array}$} & \multicolumn{2}{|c|}{ RH\% } & \multirow{2}{*}{$\begin{array}{c}\text { Wind } \\
\text { speed } \\
(\mathrm{km} / \text { day })\end{array}$} & \multirow{2}{*}{$\begin{array}{c}\text { Pan } \\
\text { evap., } \\
\text { mm/day }\end{array}$} & \multirow{2}{*}{$\begin{array}{l}\text { Rain, } \\
\text { mm/ } \\
\text { month }\end{array}$} \\
\hline & Max. & Min & Max. & Min & & & & Max. & Min & Max. & Min & & & \\
\hline Jan. & 18.2 & 8.4 & 77.5 & 60.3 & 63.2 & 2.13 & 64.0 & 19.2 & 7.6 & 91.0 & 65.4 & 46.3 & 1.98 & 78.8 \\
\hline Feb. & 17.5 & 9.6 & 75.6 & 62.1 & 71. & 3.00 & 32.7 & 20.8 & 9.0 & 90.2 & 63.9 & 61 & 2.90 & 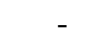 \\
\hline Mar. & 20.5 & 12.3 & 77.1 & 59.8 & 94.3 & 4.50 & 42.8 & 24.4 & 12.4 & 79.6 & 50.9 & 89.3 & 4.45 & 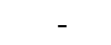 \\
\hline Apr. & 27.1 & 17.1 & 73.5 & 53.5 & & 5.15 & - & 26.0 & 15.9 & 74.2 & 43.9 & 96 & 5 & 8.5 \\
\hline May & 30.8 & 20.8 & 75.7 & 50.1 & 100.1 & 5.72 & - & 31.4 & 21.8 & 75.0 & 45.8 & 102.7 & 6.13 & 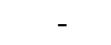 \\
\hline Jun. & 33.6 & 23.5 & 79.6 & 50.8 & 104.0 & 6.49 & - & 32.4 & 24.0 & 74.6 & 51.3 & 115.4 & 6.61 & - \\
\hline Jul. & 33.2 & 25.3 & 84.1 & 53.0 & 91.7 & 6.05 & - & 32.3 & 24.3 & 79.6 & 54.7 & 111.0 & 6.11 & - \\
\hline Aug. & 34.7 & 25.0 & 84.9 & 52.1 & & & 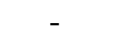 & 33.8 & 24.8 & 83.6 & 60.5 & 90 & 13 & - \\
\hline Sep. & 32.3 & 22.7 & 82.9 & 52.3 & 86.3 & 6.60 & - & 32.5 & 22.9 & 81.0 & 56.6 & 87.6 & 3.82 & - \\
\hline Oct. & 29.9 & 20.6 & 85.2 & 55.3 & 74.2 & 4.30 & 6.6 & 27.8 & 19.4 & 76.2 & 57.4 & 109.0 & 2.87 & - \\
\hline Nov. & 25.3 & 15.5 & 89.2 & 61.8 & 57.0 & 1.87 & 29.3 & 25.4 & 15.1 & 87.0 & 64.4 & 68.7 & 2.28 & - \\
\hline Dec. & 21.4 & 10.6 & 84.8 & 60.8 & 63.0 & 2.27 & 23.0 & 19.6 & 8.5 & 92.1 & 67.6 & 52.7 & 0.42 & 77.3 \\
\hline
\end{tabular}

Source: Meteorological station at Sakha $31^{\circ}-07^{`} \mathrm{~N}$ latitude, $30^{\circ}-57^{`}$ E longitude, elevation $6 \mathrm{~m}$.

The trees planted in square system of four meters (260 trees/feddan), irrigated via surface irrigation and subjected to common horticultural practices at this region. The initial soil physical and chemical characters and moisture constant of the experimental site and chemical analysis of organic manures were determined according to the standard methods described by (Black, 1983 and Kulte, 1986). The data of tested soil and organic manures are shown in Table (2a-c).
The experiment was arranged as split plot in randomized complete block design, each treatment was replicated three times with two trees per each. The main plots were assigned to three irrigation regimes i.e. irrigated at $70 \%\left(\mathrm{I}_{1}\right), 50 \%\left(\mathrm{I}_{2}\right)$ and $30 \%\left(\mathrm{I}_{3}\right)$ of available soil water (AW), while the subplots were assigned to seven fertilization treatments representing partial or total replacing mineral nitrogen fertilizer by organic (cattle or chicken) manures. 
Table (2a):Some initial chemical and physical characters of the studied soil sample

\begin{tabular}{|c|c|c|}
\hline \multirow{2}{*}{ Soil variable } & \multicolumn{2}{|c|}{ Soil depth (cm) } \\
\hline & 0-30 & $30-60$ \\
\hline $\mathrm{pH}$ value & 7.9 & 7.8 \\
\hline $\mathrm{EC}(\mathrm{dS} / \mathrm{m})$ & 1.94 & 2.32 \\
\hline SAR & 7.91 & 8.15 \\
\hline OM $(\%)$ & 1.56 & 1.23 \\
\hline $\mathrm{CaCO}_{3}$ & 3.61 & 3.82 \\
\hline Porosity \% & 46.70 & 42.21 \\
\hline \multicolumn{3}{|c|}{ Soluble cations (meq/L) } \\
\hline $\mathrm{Na}^{+}$ & 12.62 & 14.20 \\
\hline $\mathrm{K}^{+}$ & 0.46 & 0.55 \\
\hline $\mathrm{Ca}^{++}$ & 4.04 & 4.76 \\
\hline $\mathrm{Mg}^{++}$ & 2.22 & 4.92 \\
\hline \multicolumn{3}{|c|}{ Soluble anions (meq/L) } \\
\hline $\mathrm{Cl}^{-}$ & 8.82 & 11.15 \\
\hline $\mathrm{HCO}_{3}^{-}$ & 3.54 & 5.12 \\
\hline $\mathrm{CO}_{3}^{--}$ & 0.00 & 0.00 \\
\hline $\mathrm{SO}_{4}^{--}$ & 6.98 & 8.16 \\
\hline \multicolumn{3}{|c|}{ Particle size distribution } \\
\hline Sand & 22.84 & 23.41 \\
\hline Silt & 28.17 & 26.36 \\
\hline Clay & 48.99 & 50.23 \\
\hline Textural grade & Clay & Clay \\
\hline
\end{tabular}

OM= Organic matter

Table (2b):Soil moisture constant for the experimental site.

\begin{tabular}{lcccc}
\hline $\begin{array}{l}\text { Soil depth } \\
(\mathbf{c m})\end{array}$ & Field capacity $(\boldsymbol{\%})$ & $\begin{array}{c}\text { Permanent wilting } \\
\text { point \% }\end{array}$ & Available water \% & Bulk density $\left(\mathbf{g} / \mathbf{c m}^{\mathbf{3}}\right)$ \\
\hline $0-15$ & 45.19 & 23.64 & 21.55 & 1.16 \\
$15-30$ & 41.36 & 21.66 & 19.70 & 1.29 \\
$30-45$ & 38.48 & 19.85 & 18.63 & 1.34 \\
$45-60$ & 36.41 & 18.92 & 17.49 & 1.40 \\
Average & 40.36 & 21.02 & 19.34 & 1.30 \\
\hline
\end{tabular}

Table (2c):Some chemical analysis of the used organic manures.

\begin{tabular}{lcc}
\hline Variable & Cattle manure & Chicken manure \\
\hline $\mathrm{pH}$ & 7.52 & 7.22 \\
$\mathrm{EC}(\mathrm{dS} / \mathrm{m})$ & 4.62 & 3.45 \\
$\mathrm{OM} \%$ & 39.62 & 42.58 \\
$\mathrm{OC} \%$ & 23.03 & 24.76 \\
$\mathrm{C} / \mathrm{N} \mathrm{ratio}$ & 12.87 & 10.76 \\
$\mathrm{CaCO} \%$ & 1.22 & 2.41 \\
$\mathrm{~N} \%$ & 1.80 & 2.30 \\
$\mathrm{P} \%$ & 0.32 & 0.78 \\
$\mathrm{~K} \%$ & 1.25 & 1.51 \\
$\mathrm{Fe}(\mathrm{ppm})$ & 372.38 & 445.63 \\
$\mathrm{Mn}(\mathrm{ppm})$ & 291.18 & 216.81 \\
$\mathrm{Zn}(\mathrm{ppm})$ & 143.52 & 262.34 \\
\hline
\end{tabular}

$\overline{\mathrm{OM}}=$ Organic matter $\quad \mathrm{OC}=$ Organic carbon

Amount of irrigation water applied for each treatment was determined according to soil moisture content in the soil sample taken from consecutive depth of $15 \mathrm{~cm}$ down to depth of $60 \mathrm{~cm}$ even before irrigation at (70\%, 50\% and $30 \%$ of available soil water) to reach its field capacity with 3230, 2851 and $2652 \mathrm{~m}^{3} / \mathrm{fed} /$ season, distributed on 17, 9 and 6 irrigations, respectively as presented in Table (3).

Submerged orifice with fixed dimensions was used to measure the amount of applied water as the following equation of Michael (1978).

$$
\mathrm{Q}=\mathrm{CA} \sqrt{2 \mathrm{gh}}
$$

Where:

$\mathrm{Q}=$ Discharge through orifice $(\mathrm{L} / \mathrm{sec}$.)

$\mathrm{C}=$ Coefficient of discharge (0.61).

$\mathrm{A}=$ Cross section area of the orifice $\left(\mathrm{cm}^{2}\right)$.

$\mathrm{g}=$ Acceleration due to gravity, $\mathrm{cm} / \mathrm{sec}^{2}\left(981 \mathrm{~cm} / \mathrm{sec}^{2}\right)$. $\mathrm{h}=$ Pressure head, over the orifice center $(\mathrm{cm})$. 
Table (3): The quantity of irrigation water applied $\left(\mathrm{m}^{3} /\right.$ feddan) in the different irrigation treatments during each growing season.

\begin{tabular}{lccc}
\hline Irrigation treatments & Irrigation number & $\begin{array}{c}\text { Amount of each irriga. Water } \\
\text { Depth, cm }\end{array}$ & $\begin{array}{c}\text { Water } \\
\text { applied } \\
\mathbf{m}^{\mathbf{3} / \mathbf{f e d} .}\end{array}$ \\
\hline $70 \%$ available soil water & 17 & 4.524 & 3230 \\
$50 \%$ available soil water & 9 & 7.543 & 316.8 \\
$30 \%$ available soil water & 6 & 10.421 & 438.7 \\
\hline
\end{tabular}

The fertilization treatments representing various levels of nitrogen fertilization (inorganic and organic). Each fertilization treatment had under the same recommended nitrogen level of $400 \mathrm{~g} \mathrm{~N} /$ tree/season according to MALR (2003).

The mineral nitrogen fertilizer (inorganic $\mathrm{N}$ source) was added in the form of ammonium nitrate, $\mathrm{NH}_{4} \mathrm{NO}_{3}(33.5 \% \mathrm{~N})$ at three unequal doses $40 \%$ at growing start $\left(1^{\text {st }}\right.$ week of March, $30 \%$ after fruit setting in April, and $30 \%$ at one month later in May of each season. Meanwhile, organic-N was applied as cattle $(1.8 \mathrm{~N} \%)$ or chicken $(2.3 \% \mathrm{~N})$ manures taken from the same farm added superficially and mixed into the root zone under shedding of the tree canopy once in midDecember of each season. The application of these fertilizers were arranged as follows:

$\mathrm{F}_{1}$ : $100 \%$ mineral $\mathrm{N}$ fertilizer $(1200 \mathrm{~g}$ per tree ammonium nitrate $33.5 \% \mathrm{~N}$ ) $=400 \mathrm{~g} \mathrm{~N}$ per tree as the recommended dose (MALR, 2003).

$\mathrm{F}_{2}: 50 \%$ cattle manure $(11.11 \mathrm{~kg}$ per tree $)+50 \%$ mineral $\mathrm{N}$ fertilizer $(600 \mathrm{~g}$ per tree ammonium nitrate $33.5 \% \mathrm{~N})$.

$\mathrm{F}_{3}: 75 \%$ cattle manure $(16.67 \mathrm{~kg}$ per tree $)+25 \%$ mineral $\mathrm{N}$ fertilizer $(300 \mathrm{~g}$ per tree ammonium nitrate $33.5 \% \mathrm{~N})$.

$\mathrm{F}_{4}: 100 \%$ cattle manure $(22.22 \mathrm{~kg}$ per tree $)+$ zero mineral $\mathrm{N}$ fertilizer.

$\mathrm{F}_{5}: 50 \%$ chicken manure $(8.70 \mathrm{~kg}$ per tree $)+50 \%$ mineral $\mathrm{N}$ fertilizer $(600 \mathrm{~g}$ per tree ammonium nitrate $33.5 \% \mathrm{~N})$.

$\mathrm{F}_{6}: 75 \%$ chicken manure $(13.05 \mathrm{~kg}$ per tree $)+25 \%$ mineral $\mathrm{N}$ fertilizer (300 g per tree ammonium nitrate $33.5 \% \mathrm{~N}$ ).

$\mathrm{F}_{7}: 100 \%$ chicken manure $(17.40 \mathrm{~kg}$ per tree $)+$ zero mineral $\mathrm{N}$ fertilizer.

$\mathrm{P}$ and $\mathrm{K}$ fertilizers were applied at constant rates for all experimental trees i.e. $0.750 \mathrm{~kg}$ calcium super phosphate $\left(15.5 \% \mathrm{P}_{2} \mathrm{O}_{5}\right)+0.45 \mathrm{~kg}$ potassium sulfate $\left(48 \% \mathrm{~K}_{2} \mathrm{O}\right) /$ tree/season.

Measurements and determinations:

1.Estimating fruit set and preharvest fruit drop percentages:

On April $8^{\text {th }}$ fruit set\% was estimated by counting the total number of flowers and fruits which was developed on the selected main branches (four-year old). The number of preharvest dropped fruits was recorded at June drop, then the percentage of preharvest fruit drop (as an average) was calculated in ratio to the total number of fruits harvested per tree.

\section{Yield and fruit quality:}

At harvest time (June, $23^{\text {rd }}$ and June $25^{\text {th }}$ ) in 2012 and 2013 seasons, respectively yield as number of fruits and weight $(\mathrm{kg})$ per tree were recorded, then total yield (ton/fed) was calculated. Ten mature fruits were calculated at random to determine fruit weight $(\mathrm{g})$, volume $\left(\mathrm{cm}^{3}\right)$, dimensions $(\mathrm{cm})$, fruit firmness $\left(\mathrm{Lb} / \mathrm{in}^{2}\right)$ and skin colour \% visually. Juice samples were prepared to determine total soluble solids (TSS) by using galliles hand refractometer and total titratable acidity $\%$ as malic acid (A.O.A.C., 1990). Nitrate $\left(\mathrm{NO}_{3}{ }^{-}\right)$and nitrite $\left(\mathrm{NO}_{2}{ }^{-}\right)$contents as ppm in the juice were determined according to method that outlined by Sen and Donaldson (1978). Anthocynanin pigments content in fruit skin $\mu \mathrm{g} / \mathrm{cm}^{2}$ were determined colourimetrically according to Ranganna (1979).

\section{Some water relations:}

a. Water consumptive use (CU):

Soil moisture content was determined (on weight basis) before and after each irrigation to calculate water consumptive use (CU) or actual evapotranspiration (ETa) basis on soil moisture depletion by using the following equation according to Hansen et al. (1979).

$$
\mathrm{CU}=\sum_{\mathrm{i}=1}^{\mathrm{i}-4} \mathrm{Di} \times \mathrm{D}_{\mathrm{bi}} \times \frac{\mathrm{Pw}_{2}-\mathrm{Pw}_{1}}{100}
$$

Where:

$\mathrm{CU}=$ Water consumptive use $(\mathrm{cm})$ in the effective depth $(60 \mathrm{~cm})$.

$\mathrm{Di} \quad=$ Soil layer depth $(15 \mathrm{~cm}$ each)

Dbi=Soil bulk density $\left(\mathrm{g} / \mathrm{cm}^{2}\right)$ for this depth.

$\mathrm{P}_{\mathrm{w} 1} \quad=$ Soil moisture percentage before irrigation

$\mathrm{P}_{\mathrm{w} 2}=$ Soil moisture percentage, 48 hours after irrigation

i $\quad=$ Number of soil layer (each $15 \mathrm{~cm}$ depth)

b. Water use efficiency (WUE):

Water use efficiency (WUE) or water productivity (PW) was computed according to the following equation described by Ali et al. (2007):

$\mathrm{WUE}=\frac{\mathrm{Y}}{\mathrm{CU}}$

Where:

WUE $=$ Water use efficiency $\left(\mathrm{kg} / \mathrm{m}^{3}\right)$

Y $\quad=$ Yield $(\mathrm{kg} / \mathrm{fed}$.)

$\mathrm{CU} \quad=$ Water consumptive use $\left(\mathrm{m}^{3} / \mathrm{fed}\right.$.)

c. Productivity of irrigation water (PIW):

Productivity of irrigation water (PIW) was estimated according to Ali et al. (2007) as follow: 


$$
\mathrm{PIW}=\frac{\mathrm{Y}}{\mathrm{IWa}}
$$

Where:

PIW =Productivity of irrigation water $\left(\mathrm{kg} / \mathrm{m}^{3}\right)$

Y $\quad=$ Yield $(\mathrm{kg} / \mathrm{fed}$.)

IWa =Irrigation water applied $\left(\mathrm{m}^{3} / \mathrm{fed}\right.$.)

Data were statistically analyzed according to Snedecor and Cochran (1990) and LSD test at a level of 0.05 was used for comparing among averages.

\section{RESULTS AND DISCUSSION}

\section{Fruit setting and preharvest fruit dropping:}

Data listed in Table (4) clearly show that percentages of fruit set and preharvest fruit drop were significantly influenced by irrigation and organic fertilization treatments and their interaction in the two seasons. Increasing irrigation rate from $30 \%$ to $50 \%$ or $70 \%$ of (AW) markedly increased fruit set percentage. The difference between $50 \%$ AW $\left(\mathrm{I}_{2}\right)$ and $70 \%$ AW $\left(\mathrm{I}_{1}\right)$ was insignificant. On the contrary, preharvest fruit drop percentage was decreased as the level of irrigation was increased. So, under deficit irrigation regime $30 \%$ AW $\left(\mathrm{I}_{3}\right)$, lowest fruit set \% and highest preharvest fruit drop \% were recorded. These results could be attributed to lower photosynthetic rate under drought conditions (Mpelasoka et al., 2001). These findings are in harmony with those obtained by George and Nissem (2002), Mikhael and Mady (2007) and Fallahi et al. (2010) on apple and ElAbd et al. (2012) on orange who concluded that, as the severity of drought increased fruit set was reduced but preharvest fruit drop was increased. With respect to the effect of organic fertilization treatments, the obtained data indicated that highest fruit set percentages were recorded with tree received mixed organic and mineral nitrogen fertilizers $50 \%$ cattle or chicken manure plus $50 \%$ mineral fertilizer $\left(\mathrm{F}_{2} \& \mathrm{~F}_{5}\right)$ followed by $75 \%$ cattle or chicken manure plus $25 \%$ mineral fertilizer $\left(\mathrm{F}_{3} \& \mathrm{~F}_{6}\right)$ treatments compared to other trees received $100 \%$ mineral fertilizer $\left(\mathrm{F}_{1}\right)$, or $100 \%$ cattle or chicken manures $\left(F_{4} \& F_{7}\right)$ which recorded the least percentages. However, the least significant preharvest fruit drop percentages were obtained by trees fertilized with $\mathrm{F}_{2}(50 \%$ cattle manure plus $50 \%$ mineral $\mathrm{N}$ fertilizer) and $\mathrm{F}_{5}(50 \%$ chicken manure plus $50 \%$ mineral $\mathrm{N}$ fertilizer) were as the highest percentages belonged to trees treated with mineral fertilizer alone. Other treatments show the intermediate values in the two seasons. The positive effect of organic manure on increasing fruit set and reducing fruit drop might be due to enhancing root growth and increasing the absorption of nutrients especially $\mathrm{Ca}^{++}$via roots. These results are in complete agreement with those of Abd El-Salam et al. (2009) who mentioned that the combination of mineral nitrogen with organic fertilizer increased fruit set $\%$ but decreased preharvest fruit drop\% of Washington Navel orange. Moreover, Mansour et al. (2007) pointed out that, application of mineral, organic and bioforms of $\mathrm{N}$ together was significantly accompanied with reducing preharvest fruit dropping\% of "Anna" apple trees compared to using $\mathrm{N}$ as $100 \%$ mineral source. However, the interaction ( $\mathrm{I} \times \mathrm{F}$ ) was significant in the two seasons and the best interactions were $\left(\mathrm{I}_{1} \times \mathrm{F}_{2}\right),\left(\mathrm{I}_{1} \times \mathrm{F}_{5}\right),\left(\mathrm{I}_{2} \times \mathrm{F}_{2}\right)$ and $\left(\mathrm{I}_{2} \times \mathrm{F}_{5}\right)$ which gave the highest fruit set and least preharvest fruit drop percentage as shown in Table (4).

\section{Yield: \\ a.Number of fruits per tree:}

Data obtained in Table (4) revealed that number of fruits per "Anna" apple tree was gradually increased by irrigation rate increase and the highest number of fruits was produced by $\left(\mathrm{I}_{1}\right)$ while the least number was obtained under deficit irrigation regime. Such results could be attributed to the role of irrigation in increasing fruit set and reducing preharvest fruit drop. Similar results were obtained by Mikhael and Mady (2007) on apple and Moursi and Abo El-Enien (2015) on Navel orange. The data also exhibited no significant reduction in number of fruits per tree when half of recommended $\mathrm{N}$ dose was applied in organic source $\left(\mathrm{F}_{2} \& \mathrm{~F}_{5}\right) 50 \%$ cattle or chicken manure $+50 \%$ mineral fertilizer as compared to the use of mineral fertilizer alone. Meanwhile, added organic manures (cattle or chicken) alone greatly decreased number of fruits per tree in both seasons. Such findings are in harmony with those of Abd El-Salam et al. (2009) on "Navel" orange trees. The interaction was significant and the highest number of fruits per tree obtained by $\left(\mathrm{I}_{1} \times \mathrm{F}_{1}\right),\left(\mathrm{I}_{1} \times \mathrm{F}_{2}\right),\left(\mathrm{I}_{1} \times \mathrm{F}_{5}\right)$, $\left(I_{2} \times F_{1}\right),\left(I_{2} \times F_{2}\right)$ and $\left(I_{2}\right.$ and $\left.F_{5}\right)$ without any significant differences among them while the least number of fruits recorded with $\left(\mathrm{I}_{3} \times \mathrm{F}_{3}\right)$ and $\left(\mathrm{I}_{3} \times \mathrm{F}_{7}\right)$ interactions.

\section{b.Yield (kg/tree) and total yield (ton/fed.):}

As shown in Table (4), yield (kg/tree) and total yield (ton/fed.) of "Anna" apple trees were gradually decreased by reducing irrigation level from 70 to $30 \%$ of AW. The maximum significant yield were fruited by trees received the high rate of irrigation $70 \%$ AW descendingly followed by treated with $50 \%$ AW, while the minimum values were produced under deficit irrigation one $30 \% \mathrm{AW}$ in both seasons. These findings might be due to the role of irrigation in increasing number of fruits per tree and improving average fruit weight. Such results are in line with those obtained by Naor et al. (1997) on apple, Abd El-Samad et al. (2006) on pear, Ibrahim and Abd El-Samad (2009) on pomegranate and Mikhael et al. (2010) on peach who concluded that great reduction in fruit yield was noticed in deficit irrigation regime compared with the wet treatment. Moreover, yield as ( $\mathrm{kg} /$ tree) and total yield (ton/fed.) was significantly affected by fertilization levels. The highest values were obtained when applied $50 \%$ chicken or cattle manure plus $50 \%$ mineral fertilizer $\left(\mathrm{F}_{5}\right.$ and $\left.\mathrm{F}_{2}\right)$ followed by adding $100 \%$ mineral fertilizer $F_{1}$ while the least values belonged to fertilized with $100 \%$ cattle or chicken manures $\left(\mathrm{F}_{5}\right.$ and $\left.\mathrm{F}_{7}\right)$ in both seasons. The positive action of different $\mathrm{N}$ sources on growth and nutritional status could result in enhancing the yield. The effect of them in increasing fruit set and reducing preharvest fruit drop could give another explanation. Similar conclusion was also achieved by Mansour et al. (2007) and Mikhael and Mady (2007) on apple, Garhwal et al. (2014) on mandarin, El-Wasfy and Abd El-Rahman (2014) on date palm and Wassal et al. (2015) on fig. Meanwhile, the interaction was 
significant in the two seasons and the highest yield (kg/tree) and (ton/fed.) were produced when "Anna" apple trees were grown under 70 or $50 \%$ of available soil water and received $50 \%$ cattle or chicken manure with half the recommended dose of mineral nitrogen fertilizer $\left(\mathrm{I}_{1} \times \mathrm{F}_{2}\right),\left(\mathrm{I}_{1} \times \mathrm{F}_{5}\right),\left(\mathrm{I}_{2} \times \mathrm{F}_{2}\right)$ and/or $\left(\mathrm{I}_{2} \times \mathrm{F}_{5}\right)$ combination treatments without significant differences among them. While, trees subjected under severe water stress $(30 \% \mathrm{AW})$ and fertilized by $100 \%$ cattle or chicken manure in $\left(\mathrm{I}_{3} \times \mathrm{F}_{4}\right)$ or $\left(\mathrm{I}_{3} \times \mathrm{F}_{7}\right)$ interaction gave the least significant values of yield.

Table (4): Fruit set, preharvest fruit drop and yield of "Anna" apple trees as influenced by irrigation and organic fertilization treatments and their interaction during 2012 and 2013 seasons.

\begin{tabular}{|c|c|c|c|c|c|c|c|c|c|c|c|}
\hline \multirow{2}{*}{$\begin{array}{l}\text { Treatments } \\
\text { Irrigation } \\
\text { regime (I) }\end{array}$} & \multirow{2}{*}{$\begin{array}{l}\text { Fert. } \\
(\mathbf{F})\end{array}$} & \multicolumn{2}{|c|}{ Fruit set \%* } & \multicolumn{2}{|c|}{$\begin{array}{l}\text { Preharvest fruit } \\
\text { drop }(\%)\end{array}$} & \multicolumn{6}{|c|}{ Yield } \\
\hline & & 2012 & 2013 & 2012 & 2013 & 2012 & 2013 & 2012 & 2013 & 2012 & 2013 \\
\hline \multirow{7}{*}{$\mathrm{I}_{1}$} & $\mathrm{~F}_{1}$ & 20.84 & 21.19 & 10.46 & 9.91 & 201 & 206 & 32.48 & 34.49 & 8.44 & 8.97 \\
\hline & $\mathrm{F}_{2}$ & 26.65 & 26.85 & 7.33 & 6.69 & 200 & 207 & 33.96 & 36.49 & 8.83 & 9.49 \\
\hline & $\mathrm{F}_{3}$ & 25.18 & 25.60 & 7.92 & 7.32 & 196 & 202 & 30.14 & 31.57 & 7.84 & 8.21 \\
\hline & $\mathrm{F}_{4}$ & 21.59 & 21.96 & 9.74 & 9.15 & 192 & 199 & 27.14 & 29.29 & 7.06 & 7.61 \\
\hline & $\mathrm{F}_{5}$ & 26.32 & 26.69 & 7.65 & 7.14 & 198 & 205 & 34.76 & 36.60 & 9.04 & 9.52 \\
\hline & $\mathrm{F}_{6}$ & 24.83 & 25.23 & 8.52 & 8.15 & 198 & 203 & 30.94 & 32.77 & 8.04 & 8.52 \\
\hline & $\mathrm{F}_{7}$ & 21.05 & 21.51 & 9.81 & 9.24 & 194 & 200 & 28.13 & 30.49 & 7.32 & 7.93 \\
\hline \multirow[t]{4}{*}{ Averag } & & 23.78 & 24.15 & 8.78 & 8.23 & 197 & 203 & 31.08 & 33.10 & 8.08 & 8.61 \\
\hline & $\mathrm{F}_{1}$ & 17.79 & 18.17 & 12.58 & 11.94 & 197 & 203 & 30.17 & 32.23 & 7.84 & 8.38 \\
\hline & $\mathrm{F}_{2}$ & 23.45 & 23.75 & 9.34 & 8.81 & 204 & 207 & 33.10 & 35.05 & 8.61 & 9.11 \\
\hline & $\mathrm{F}_{3}$ & 22.05 & 22.45 & 10.07 & 9.46 & 183 & 188 & 26.64 & 27.90 & 6.93 & 7.25 \\
\hline \multirow[t]{4}{*}{$\mathrm{I}_{2}$} & $\mathrm{~F}_{4}$ & 18.41 & 18.84 & 11.90 & 11.39 & 176 & 183 & 23.53 & 25.64 & 6.12 & 6.67 \\
\hline & $\mathrm{F}_{5}$ & 23.18 & 23.64 & 9.79 & 9.28 & 198 & 207 & 33.32 & 35.57 & 8.66 & 9.25 \\
\hline & $\mathrm{F}_{6}$ & 21.70 & 22.03 & 10.63 & 10.27 & 184 & 191 & 27.33 & 29.24 & 7.11 & 7.60 \\
\hline & $\mathrm{F}_{7}$ & 17.92 & 18.31 & 11.94 & 11.46 & 177 & 185 & 24.37 & 26.66 & 6.34 & 6.93 \\
\hline \multirow[t]{4}{*}{ Average } & & 20.64 & 21.03 & 10.89 & 10.37 & 188 & 195 & 28.35 & 30.33 & 7.37 & 7.88 \\
\hline & $\mathrm{F}_{1}$ & 15.31 & 15.90 & 14.33 & 13.79 & 183 & 189 & 26.34 & 27.74 & 6.85 & 7.21 \\
\hline & $\mathrm{F}_{2}$ & 21.03 & 21.97 & 10.08 & 9.41 & 173 & 180 & 25.98 & 28.15 & 6.75 & 7.32 \\
\hline & $\mathrm{F}_{3}$ & 19.65 & 20.38 & 12.19 & 11.24 & 165 & 171 & 21.72 & 23.47 & 5.65 & 7.10 \\
\hline \multirow[t]{4}{*}{$\mathrm{I}_{3}$} & $\mathrm{~F}_{4}$ & 15.97 & 16.85 & 13.67 & 13.18 & 154 & 162 & 18.56 & 20.93 & 4.83 & 5.44 \\
\hline & $\mathrm{F}_{5}$ & 20.73 & 21.42 & 11.57 & 11.15 & 175 & 183 & 27.60 & 29.37 & 7.18 & 7.64 \\
\hline & $\mathrm{F}_{6}$ & 19.34 & 20.36 & 12.41 & 11.94 & 168 & 176 & 22.51 & 24.70 & 5.85 & 6.42 \\
\hline & $\mathrm{F}_{7}$ & 15.36 & 16.12 & 13.81 & 13.23 & 159 & 167 & 20.27 & 22.04 & 5.27 & 5.73 \\
\hline \multicolumn{2}{|c|}{ Average } & 18.20 & 19.00 & 12.58 & 11.99 & 168 & 175 & 23.28 & 25.20 & 6.05 & 6.69 \\
\hline \multirow{7}{*}{ Average } & $\mathrm{F}_{1}$ & 17.98 & 18.42 & 12.46 & 11.88 & 194 & 199 & 29.66 & 31.49 & 7.71 & 8.19 \\
\hline & $\mathrm{F}_{2}$ & 23.71 & 24.19 & 8.92 & 8.30 & 192 & 198 & 31.01 & 33.23 & 8.06 & 8.64 \\
\hline & $\mathrm{F}_{3}$ & 22.29 & 22.81 & 10.06 & 9.34 & 181 & 187 & 26.17 & 27.65 & 6.81 & 7.52 \\
\hline & $\mathrm{F}_{4}$ & 18.66 & 19.22 & 11.77 & 11.24 & 174 & 183 & 23.08 & 25.29 & 6.00 & 6.57 \\
\hline & $\mathrm{F}_{5}$ & 23.41 & 23.92 & 9.67 & 9.19 & 190 & 198 & 31.89 & 33.85 & 8.29 & 8.80 \\
\hline & $\mathrm{F}_{6}$ & 21.96 & 22.54 & 10.52 & 10.12 & 183 & 190 & 26.93 & 28.90 & 7.00 & 7.51 \\
\hline & $\mathrm{F}_{7}$ & 18.11 & 18.65 & 11.85 & 11.31 & 177 & 184 & 24.26 & 26.40 & 6.31 & 6.86 \\
\hline \multirow{3}{*}{ LSD 0.05} & I & 3.831 & 3.228 & 0.650 & 0.183 & 8.6 & 6.3 & 0.686 & 0.899 & 0.163 & 0.739 \\
\hline & $\mathrm{F}$ & 1.798 & 2.848 & 0.614 & 0.364 & 7.0 & 5.1 & 1.237 & 1.580 & 0.347 & 0.411 \\
\hline & $\mathrm{I} \times \mathrm{F}$ & 3.113 & 4.932 & 1.064 & 0.631 & 12.2 & 8.9 & 2.142 & 2.737 & 0.602 & 0.712 \\
\hline
\end{tabular}

$I_{1}, I_{2}$ and $I_{3}$ : Irrigation at 70,50 and $30 \%$ of available water $(A W)$, respectively.

$\mathrm{F}_{1}: \mathbf{1 0 0 \%}$ mineral $\mathrm{N}$

$F_{2}: 50 \%$ organic $N$ (cattle manure) plus $50 \%$ mineral $N$

$F_{3}: 75 \%$ organic $N$ (cattle manure) plus $25 \%$ mineral $N$

$\mathrm{F}_{4}: \mathbf{1 0 0 \%}$ organic $\mathrm{N}$ (cattle manure)

* Fruit set \% in April $8^{\text {th }}$

$\mathrm{F}_{5}: \mathbf{5 0 \%}$ organic $\mathrm{N}$ (chicken manure) plus $50 \%$ mineral $N$

$F_{6}: 75 \%$ organic $N$ (chicken manure) plus $25 \%$ mineral $N$

$\mathrm{F}_{7}: \mathbf{1 0 0 \%}$ organic $\mathrm{N}$ (chicken manure)
Conclusively $\left(\mathrm{I}_{2} \quad \mathrm{x} \quad \mathrm{F}_{2}\right)$ and $\left(\mathrm{I}_{2} \quad \mathrm{x} \quad \mathrm{F}_{5}\right)$ were considered the best combination treatments for improving productivity of "Anna" apple trees (33.10 \& $35.05 \mathrm{~kg} /$ tree $)$ and (33.32 \& $35.57 \mathrm{~kg} /$ tree) in 2012 and 2013 seasons, respectively.

3.Physical and chemical fruit properties:

a.Fruit weight, volume and dimensions:

It is obvious from the data in Table (5) that fruit weight $(\mathrm{g})$, volume $\left(\mathrm{cm}^{3}\right)$, length and diameter $(\mathrm{cm})$ were significantly increased by raising irrigation level and the largest fruits were produced under wet irrigation regime $\mathrm{I}_{1}(70 \% \mathrm{AW})$. While, the smallest fruit were obtained under deficit irrigation rate $\mathrm{I}_{3}(30 \% \mathrm{AW})$. The reduction in fruit weight and size under deficit soil moisture content could be due to decreasing fruit cell enlargement through reducing fruit trigor early in the season beside, decreased cell water content (Li et al., 1989). Moreover, Behbudian et al. (1994) mentioned 
that the reduction in fruit size under drought conditions could be due to assimilate availability through decreased photosynthesis rate $(\mathrm{Pn})$. These findings were supported by those of George and Nissen (2002), Mikhael and Mady (2007) and Fallahi et al. (2010) on apple and Moharam and Zaen El-Deen (2011) on peach who concluded that fruit weight and size were markedly increased by irrigation.

Concerning the effect of organic manures, data presented in Table (5) revealed significant influence in fruit weight, volume and dimensions of "Anna" apple due to fertilization of organic manures. The heaviest and largest fruits were obtained by applying nitrogen requirements as $50 \%$ cattle or chicken manure $+50 \%$ mineral fertilizer followed by application of mineral fertilizer alone $(100 \%)$. Otherwise, increasing the ratio of organic manure more than $50 \%$ reduced fruit weight and size. The highest and smallest fruits were produced by trees fertilized with organic manure alone $\left(F_{3} \& F_{7}\right)$ in both seasons. These results are in accordance with those reported by Ibrahim and Abd El-Samad (2009) on pomegranate, El-Khawaga (2011) on peach and Garhwal et al. (2014) on mandarin who indicated that application of organic manure significantly improved fruit weight and size. However, the interaction (I x F) was significant in both seasons and the maximum fruit weight, volume and dimensions came from $\left(\mathrm{I}_{1} \times \mathrm{F}_{2}\right),\left(\mathrm{I}_{1}\right.$ $\left.\begin{array}{llll}\mathrm{x} & \mathrm{F}_{5}\end{array}\right),\left(\begin{array}{llll}\mathrm{I}_{2} & \mathrm{x} & \mathrm{F}_{2}\end{array}\right)$ and $\left(\begin{array}{llll}\mathrm{I}_{2} & \mathrm{x} & \mathrm{F}_{5}\end{array}\right)$ without significant differences among them, whereas the minimum values produced by $\left(\mathrm{I}_{3} \times \mathrm{F}_{4}\right)$ and $\left(\mathrm{I}_{3} \times \mathrm{F}_{7}\right)$ interactions.

Table (5)Some physical properties* of "Anna" apple fruits as influenced by irrigation and organic fertilization treatments and their interaction during 2012 and 2013 seasons.

\begin{tabular}{|c|c|c|c|c|c|c|c|c|c|c|c|}
\hline \multirow{2}{*}{$\begin{array}{l}\text { Treatments } \\
\text { Irrigation } \\
\text { regime }(I) \\
\end{array}$} & \multirow{2}{*}{$\begin{array}{l}\text { Fert. } \\
\text { (F) }\end{array}$} & \multicolumn{2}{|c|}{ Av. fruit weight (g) } & \multicolumn{2}{|c|}{$\begin{array}{l}\text { Av. fruit volume } \\
\left(\mathrm{cm}^{3}\right)\end{array}$} & \multicolumn{2}{|c|}{ Fruit length $(\mathrm{cm})$} & \multicolumn{2}{|c|}{ Fruit diameter $(\mathrm{cm})$} & \multicolumn{2}{|c|}{$\begin{array}{c}\text { Fruit firmness } \\
\left(\mathrm{lb} / \mathrm{in}^{2}\right)\end{array}$} \\
\hline & & 2012 & 2013 & 2012 & 2013 & 2012 & 2013 & 2012 & 2013 & 2012 & 2013 \\
\hline \multirow{7}{*}{$\mathrm{I}_{1}$} & $\overline{F_{1}}$ & 161.56 & 167.42 & 164.6 & 169.8 & 7.91 & 7.95 & 7.39 & 7.42 & 8.04 & 7.86 \\
\hline & $\mathrm{F}_{2}$ & 169.85 & 176.30 & 172.7 & 178.9 & 7.97 & 8.07 & 7.44 & 7.54 & 8.93 & 8.82 \\
\hline & $\mathrm{F}_{3}$ & 153.77 & 155.93 & 156.1 & 158.1 & 7.44 & 7.47 & 6.99 & 7.04 & 9.22 & 9.15 \\
\hline & $\mathrm{F}_{4}$ & 141.32 & 147.19 & 143.7 & 149.5 & 7.02 & 7.09 & 6.69 & 6.73 & 9.76 & 9.65 \\
\hline & $\mathrm{F}_{5}$ & 175.51 & 178.52 & 177.8 & 181.5 & 8.12 & 8.17 & 7.60 & 7.64 & 9.12 & 8.95 \\
\hline & $\mathrm{F}_{6}$ & 156.29 & 161.44 & 159.1 & 164.0 & 7.49 & 7.59 & 7.07 & 7.23 & 9.41 & 9.32 \\
\hline & $\mathrm{F}_{7}$ & 145.13 & 152.45 & 147.6 & 154.6 & 7.11 & 7.19 & 6.77 & 6.69 & 10.02 & 9.87 \\
\hline \multirow[t]{4}{*}{ Average } & & 157.63 & 162.75 & 160.2 & 165.2 & 7.58 & 7.65 & 7.14 & 7.18 & 9.21 & 9.09 \\
\hline & $\mathrm{F}_{1}$ & 153.16 & 158.71 & 155.2 & 160.6 & 7.59 & 7.67 & 7.09 & 7.17 & 9.37 & 9.28 \\
\hline & $\mathrm{F}_{2}$ & 162.26 & 169.28 & 164.5 & 171.7 & 7.85 & 7.91 & 7.34 & 7.39 & 10.38 & 10.32 \\
\hline & $\mathrm{F}_{3}$ & 145.18 & 148.39 & 147.4 & 150.6 & 7.12 & 7.18 & 6.72 & 6.75 & 10.73 & 10.64 \\
\hline \multirow[t]{4}{*}{$\mathrm{I}_{2}$} & $\mathrm{~F}_{4}$ & 133.79 & 140.15 & 136.1 & 142.5 & 6.71 & 6.82 & 6.27 & 6.44 & 11.21 & 11.12 \\
\hline & $\mathrm{F}_{5}$ & 168.32 & 171.82 & 171.0 & 174.4 & 7.94 & 8.01 & 7.42 & 7.49 & 10.53 & 10.41 \\
\hline & $\mathrm{F}_{6}$ & 148.46 & 153.25 & 150.7 & 155.7 & 7.22 & 7.37 & 6.75 & 6.89 & 10.91 & 10.81 \\
\hline & $\mathrm{F}_{7}$ & 137.61 & 144.11 & 140.1 & 146.8 & 6.79 & 6.87 & 6.47 & 6.54 & 11.42 & 11.29 \\
\hline \multirow[t]{4}{*}{ Average } & & 149.83 & 155.10 & 152.1 & 157.5 & 7.32 & 7.40 & 6.87 & 6.95 & 10.71 & 10.55 \\
\hline & $\mathrm{F}_{1}$ & 143.87 & 146.71 & 145.7 & 148.5 & 7.07 & 7.34 & 6.65 & 6.87 & 10.43 & 10.44 \\
\hline & $\mathrm{F}_{2}$ & 150.02 & 156.38 & 151.2 & 158.6 & 7.61 & 7.65 & 7.19 & 7.22 & 11.64 & 11.49 \\
\hline & $\mathrm{F}_{3}$ & 131.75 & 137.21 & 133.9 & 139.3 & 6.59 & 6.77 & 6.20 & 6.28 & 12.01 & 11.88 \\
\hline \multirow[t]{4}{*}{$\mathrm{I}_{3}$} & $\mathrm{~F}_{4}$ & 120.44 & 129.39 & 122.2 & 131.5 & 6.22 & 6.24 & 5.67 & 5.89 & 12.45 & 12.29 \\
\hline & $\mathrm{F}_{5}$ & 157.80 & 160.41 & 160.3 & 162.3 & 7.53 & 7.58 & 7.05 & 7.08 & 11.77 & 11.72 \\
\hline & $\mathrm{F}_{6}$ & 133.84 & 140.40 & 135.9 & 142.6 & 6.83 & 6.96 & 6.44 & 6.57 & 12.05 & 11.97 \\
\hline & $\mathrm{F}_{7}$ & 127.51 & 132.05 & 129.8 & 134.3 & 6.38 & 6.41 & 5.96 & 5.99 & 12.56 & 12.50 \\
\hline \multirow[t]{4}{*}{ Average } & & 137.89 & 143.22 & 139.9 & 145.3 & 6.89 & 6.99 & 6.45 & 6.56 & 11.84 & 11.76 \\
\hline & $\mathrm{F}_{1}$ & 152.86 & 157.61 & 155.2 & 159.6 & 7.52 & 7.65 & 7.04 & 7.15 & 9.28 & 9.19 \\
\hline & $\mathrm{F}_{2}$ & 160.71 & 167.32 & 162.8 & 169.7 & 7.72 & 7.88 & 7.32 & 7.38 & 10.32 & 10.21 \\
\hline & $\mathrm{F}_{3}$ & 143.57 & 147.18 & 145.8 & 149.3 & 7.05 & 7.14 & 6.64 & 6.69 & 10.65 & 10.56 \\
\hline \multirow[t]{5}{*}{ Average } & $\mathrm{F}_{4}$ & 131.85 & 138.91 & 134.0 & 141.2 & 6.65 & 6.72 & 6.21 & 6.35 & 11.14 & 11.02 \\
\hline & $\mathrm{F}_{5}$ & 167.21 & 170.25 & 169.7 & 172.7 & 7.86 & 7.92 & 7.39 & 7.40 & 10.47 & 10.36 \\
\hline & $\mathrm{F}_{6}$ & 146.20 & 151.70 & 148.6 & 154.1 & 7.18 & 7.31 & 6.75 & 6.90 & 10.79 & 10.70 \\
\hline & $\mathrm{F}_{7}$ & 136.75 & 142.87 & 139.2 & 145.2 & 6.76 & 6.82 & 6.40 & 6.41 & 11.33 & 11.22 \\
\hline & I & 5.290 & 3.289 & 4.815 & 8.106 & 0.311 & 0.238 & 0.146 & 0.762 & 0.259 & 0.163 \\
\hline \multirow[t]{2}{*}{ LSD 0.05} & $\mathrm{~F}$ & 4.420 & 6.094 & 4.639 & 7.966 & 0.321 & 0.803 & 0.113 & 0.324 & 0.279 & 0.096 \\
\hline & I $x \mathrm{~F}$ & 7.656 & 10.550 & 8.035 & 13.800 & 0.557 & 1.390 & 0.196 & 0.562 & 0.483 & 0.166 \\
\hline
\end{tabular}

$I_{1}, I_{2}$ and $I_{3}$ : Irrigation at 70,50 and $30 \%$ of available water $(A W)$, respectively.

$\mathrm{F}_{1}: \mathbf{1 0 0 \%}$ mineral $\mathrm{N}$

$F_{2}: 50 \%$ organic $N$ (cattle manure) plus $50 \%$ mineral $N$

$F_{3}: 75 \%$ organic $N$ (cattle manure) plus $25 \%$ mineral $N$ $F_{4}: 100 \%$ organic $N$ (cattle manure)

* At harvest time (June $23^{\text {rd }}$ and June $25^{\text {th }}$ ) in 2012 ad 2013 seasons.

\section{b. Fruit firmness:}

As shown in Table (5), it is clear that, reducing irrigation level and increasing rate of organic manures led to an increase in fruit firmness. The differences were significant in both seasons. However, the interaction (I x
$F_{5}: 50 \%$ organic $N$ (chicken manure) plus $50 \%$ mineral $N$

$F_{6}: 75 \%$ organic $N$ (chicken manure) plus $25 \%$ mineral $N$ $\mathrm{F}_{7}: \mathbf{1 0 0 \%}$ organic $\mathrm{N}$ (chicken manure)
F) was significant in 2012 and 2013 seasons and the firm fruits were achieved by $\left(\mathrm{I}_{3} \times \mathrm{F}_{3}\right),\left(\mathrm{I}_{3} \times \mathrm{F}_{4}\right),\left(\mathrm{I}_{3} \times \mathrm{F}_{6}\right)$ and $\left(I_{3} \times F_{7}\right)$ while the control $\left(I_{1} \times F_{1}\right)$ gave less fruit firmness. The reduction in fruit firmness might be due to increasing fruit volume and reducing calcium 
concentration as influenced by irrigation and fertilizers application. These results coincided with those obtained by Mikhael et al. (2010) who reported that deficit irrigation regime induced significantly higher fruit firmness. Furthermore, Salama et al. (2012) concluded that the values of fruit firmness of Sewy date fruit were increased when $100 \%$ of nitrogen was applied completely via organic form compared to added $100 \%$ mineral nitrogen fertilizer.

c.Total soluble solids and total acidity percentage:

Data in Table (6) revealed that fertilization of "Anna" apple trees with recommended rate of $\mathrm{N}$ via 50 to $100 \%$ organic manure (cattle or chicken) gradually increased total soluble content \% compared to using $\mathrm{N}$ completely via inorganic source. Maximum values were recorded with application of cattle or chicken manure alone with (13.31 \& 13.46) or (13.51\& 13.69), in 2012 and 2013 seasons, respectively. Meanwhile, the lowest significant values were recorded with $100 \%$ mineral fertilizer (11.89\& 12.0) in 2012 and 2013 seasons. The advancing effect on ripening of organic manures could explain the present results. Similar observations were also achieved by Selem and Telep (2008) and Shahean et al. (2013) on grapevine, Mansour et al. (2007) on apple and Wassel et al. (2015) on fig who mentioned that promotion of fruit quality in terms of increasing TSS was associated with decreasing the percentage of mineral nitrogen fertilizer and in the meantime increasing the percentage of organic $\mathrm{N}$ form in the fertilization program. The data also indicated that, there was a progressively increase in fruit TSS content with increasing the rate of irrigation from $30 \%$ to $70 \%$ AW in $1^{\text {st }}$ and $2^{\text {nd }}$ seasons. These findings might be due to advance fruit maturity under drought condition. These results are in accordance with those of Mikhael et al. (2010) who found that the values of soluble solids content (SSC) in fruits of "Dessert Red" peach trees increase by decreasing the level of irrigation regime from $80 \%$ to $60 \%$ field capacity (FC). Other wise, Kaya et al. (2010) noticed that there were no significant differences for the tested irrigation regimes in total soluble content of apricot fruit. However, the interaction (I $\mathrm{x}$ F) was significant in the two seasons and the highest values recorded with $\left(\mathrm{I}_{3} \times \mathrm{F}_{7}\right)$ and $\left(\mathrm{I}_{3} \times \mathrm{F}_{4}\right)$ in both seasons.

Data of Table (6) exhibited that, total acidity was not significantly influenced by all the tested irrigation and fertilization treatments and their interaction in both seasons. Similar results were also obtained by Mikhael and Mady (2007) and Kaya et al. (2010) on irrigation apple and apricot trees and Abd El-Migeed et al.(2007) on organic fertilization of Navel orange trees.

\section{d.Nitrate and nitrite content:}

From the data presented in Table (6), it could be concluded that nitrate and nitrite contents in "Anna" apple fruit juice were significantly decreased by different cattle or chicken manure treatments in the two seasons of study comparing with $100 \%$ mineral N fertilizer. This means that replacing partially or completely through using 50, 75 and $100 \% \mathrm{~N}$ as cattle or chicken manure instead of $100 \%$ mineral $\mathrm{N}$ had a beneficial effect on reducing nitrate and nitrite in fruit juice. This result could be described that using organic materials are often considered as a desirable nitrogen source because the nitrogen is in the mineralization immobilization cycle longer and thus is more slow available (Hallberg and Keeriey, 1993). Furthermore, the addition of organic manure as slow release for $\mathrm{N}$ resulted in a further reduction in $\mathrm{NO}_{3}$ accumulation in the plant in comparison with mineral nitrogen as fast release for $\mathrm{N}$ (El-Sisy, 2000). Such results are in harmony with those obtained by Abd El-Migeed et al. (2007) on Navel orange, Salama et al. (2012) on date palm and Abd El-Monem et al. (2008) and Shaheen et al. (2013) on grapevine. They concluded that nitrate and nitrite content of fruits were significantly reduced by decreased the amount of $\mathrm{N}$ mineral fertilizer.

Data also revealed that, nitrate and nitrite content were not significantly affected by all tested irrigation treatments used in this study in both seasons. The interaction (I x F) was significant in 2012 and 2013 seasons and the highest values of $\mathrm{NO}_{3}$ and $\mathrm{NO}_{2}$ (ppm) in fruit juice were detected when $100 \%$ mineral fertilizer was applied to soil irrigated at $30 \% \mathrm{AW}\left(\mathrm{I}_{3} \mathrm{x}\right.$ $F_{1}$ ). Meanwhile, these values were decreased with partial or complete substitution of mineral fertilizer by organic manure under high irrigation regime $(70 \% \mathrm{AW})$ and the minimum values came from $\left(\mathrm{I}_{1} \times \mathrm{F}_{4}\right)$ or $\left(\mathrm{I}_{1} \times \mathrm{F}_{7}\right)$ interaction in both seasons.

\section{e.Fruit color:}

With respect to the impact of irrigation regimes and fertilization treatments and their interaction on red color \% and skin anthocyanin content of "Anna" apple fruit, the data of 2102 and 2013 seasons tabulated in Table (6) and illustrated in Fig. (1) revealed that, the percent of red color and the values of anthocyanin content in apple fruit skin were increased by reducing irrigation regime and increasing application rate of organic manures. The interaction was significant during the two seasons and the highest values recorded with $\left(\mathrm{I}_{2}\right.$ $\left.\begin{array}{lll}\mathrm{x} & \mathrm{F}_{2}\end{array}\right)$ and $\left(\mathrm{I}_{2} \quad \mathrm{x} \quad \mathrm{F}_{5}\right)$ without significant difference between them in both seasons. While, the control $\left(\mathrm{I}_{1} \mathrm{X}\right.$ $F_{1}$ ) obtained the least values. These results might be attributed to the positive action of organic application and moderate irrigation regime in the improving of biosynthesis of carbohydrate and accelerating fruit ripening (Mansour et al., 2007). These findings confirmed with those achieved by Shahien et al. (2002) on "Anna" apple and Mikhael et al. (2010) on "Dessert Red" peach indicated that, trees under deficit irrigation regime had significantly highest concentration of anthocyanin in fruit skin and higher percent of fruit color. Moreover, Masoud (2012) mentioned that fertilizing "Flame seedless" and "Ruby seedless" grapevines by organic fertilizer (compost) either alone or in combination with mineral $\mathrm{N}$ fertilizer significantly increased anthocyanin content in berry juice.

Generally, replacing mineral nitrogen by organic manures significantly improved the chemical properties of apple fruit in terms of increased TSS, slightly reduced the total acidity, reduced nitrate and nitrite content and increased anthocyanin content in fruit skin. 
Table (6):Some chemical properties* of "Anna" apple fruits as influenced by irrigation and organic fertilization treatments and their interaction during in 2012 and 2013 seasons.

\begin{tabular}{|c|c|c|c|c|c|c|c|c|c|c|c|}
\hline \multirow{2}{*}{$\begin{array}{l}\text { Treatments } \\
\text { Irrigation } \\
\text { regime (I) }\end{array}$} & \multirow[t]{2}{*}{ Fert. (F) } & \multicolumn{2}{|c|}{ TSS (\%) } & \multicolumn{2}{|c|}{ Acidity (\%) } & \multicolumn{2}{|c|}{ Nitrate (ppm) } & \multicolumn{2}{|c|}{ Nitrite (ppm) } & \multicolumn{2}{|c|}{$\begin{array}{l}\text { Skin anthocyanine } \\
\text { content }\left(\mu \mathrm{g} / \mathrm{cm}^{2}\right)\end{array}$} \\
\hline & & 2012 & 2013 & 2012 & 2013 & 2012 & 2013 & 2012 & 2013 & 2012 & 2013 \\
\hline \multirow{7}{*}{ I1 } & $\mathrm{F}_{1}$ & 11.40 & 11.33 & 0.58 & 0.56 & 39.2 & 35.6 & 2.04 & 1.92 & 12.76 & 13.74 \\
\hline & $\mathrm{F}_{2}$ & 12.07 & 12.40 & 0.54 & 0.53 & 27.8 & 23.9 & 1.06 & 0.98 & 12.81 & 14.38 \\
\hline & $\mathrm{F}_{3}$ & 12.27 & 12.67 & 0.52 & 0.49 & 22.7 & 18.5 & 0.85 & 0.69 & 14.95 & 15.38 \\
\hline & $\mathrm{F}_{4}$ & 12.80 & 12.93 & 0.50 & 0.48 & 17.9 & 15.7 & 0.62 & 0.52 & 15.42 & 16.74 \\
\hline & $\mathrm{F}_{5}$ & 12.20 & 12.13 & 0.53 & 0.50 & 30.5 & 24.2 & 1.32 & 1.22 & 13.76 & 14.47 \\
\hline & $\mathrm{F}_{6}$ & 12.47 & 12.87 & 0.49 & 0.47 & 26.2 & 22.4 & 0.94 & 0.78 & 15.83 & 15.71 \\
\hline & $\mathrm{F}_{7}$ & 12.93 & 13.07 & 0.47 & 0.44 & 19.2 & 14.8 & 0.72 & 0.56 & 16.39 & 17.13 \\
\hline \multirow[t]{4}{*}{ Average } & & 12.31 & 12.49 & 0.52 & 0.50 & 26.2 & 22.2 & 1.08 & 0.95 & 14.56 & 15.36 \\
\hline & $\mathrm{F}_{1}$ & 11.93 & 12.13 & 0.55 & 0.51 & 43.6 & 35.9 & 1.98 & 1.89 & 13.92 & 14.76 \\
\hline & $\mathrm{F}_{2}$ & 12.73 & 12.67 & 0.51 & 0.50 & 29.1 & 24.6 & 1.02 & 0.96 & 17.25 & 17.46 \\
\hline & $\mathrm{F}_{3}$ & 13.07 & 13.20 & 0.48 & 0.46 & 23.9 & 21.2 & 0.79 & 0.70 & 16.69 & 16.98 \\
\hline \multirow[t]{4}{*}{$\mathrm{I}_{2}$} & $\mathrm{~F}_{4}$ & 13.40 & 13.53 & 0.46 & 0.42 & 18.4 & 16.3 & 0.62 & 0.51 & 16.95 & 17.21 \\
\hline & $\mathrm{F}_{5}$ & 12.87 & 13.07 & 0.49 & 0.47 & 28.6 & 24.9 & 1.26 & 1.15 & 17.36 & 17.51 \\
\hline & $\mathrm{F}_{6}$ & 13.33 & 13.40 & 0.46 & 0.46 & 25.1 & 20.1 & 0.91 & 0.76 & 16.96 & 17.06 \\
\hline & $\mathrm{F}_{7}$ & 13.67 & 13.80 & 0.45 & 0.42 & 19.8 & 16.7 & 0.70 & 0.54 & 16.85 & 17.29 \\
\hline \multirow[t]{4}{*}{ Average } & & 13.00 & 13.11 & 0.49 & 0.46 & 26.9 & 22.8 & 1.04 & 0.93 & 16.57 & 16.90 \\
\hline & $\mathrm{F}_{1}$ & 12.33 & 12.53 & 0.49 & 0.47 & 44.2 & 37.4 & 1.95 & 1.84 & 14.90 & 15.54 \\
\hline & $\mathrm{F}_{2}$ & 13.27 & 13.13 & 0.46 & 0.44 & 27.5 & 24.1 & 0.97 & 0.94 & 17.19 & 17.21 \\
\hline & $\mathrm{F}_{3}$ & 13.47 & 13.40 & 0.44 & 0.43 & 24.5 & 22.4 & 0.78 & 0.65 & 17.05 & 17.26 \\
\hline \multirow[t]{4}{*}{$\mathrm{I}_{3}$} & $\mathrm{~F}_{4}$ & 13.73 & 13.93 & 0.45 & 0.41 & 18.3 & 15.4 & 0.59 & 0.48 & 17.12 & 17.38 \\
\hline & $\mathrm{F}_{5}$ & 13.33 & 13.47 & 0.45 & 0.45 & 29.7 & 26.2 & 1.22 & 1.12 & 16.61 & 17.25 \\
\hline & $\mathrm{F}_{6}$ & 13.67 & 13.73 & 0.43 & 0.42 & 24.9 & 22.9 & 0.86 & 0.72 & 17.10 & 17.29 \\
\hline & $\mathrm{F}_{7}$ & 13.93 & 14.20 & 0.42 & 0.41 & 22.5 & 17.1 & 0.67 & 0.50 & 17.16 & 17.39 \\
\hline \multirow[t]{4}{*}{ Average } & & 13.39 & 13.48 & 0.45 & 0.43 & 27.4 & 23.6 & 1.01 & 0.89 & 16.73 & 17.05 \\
\hline & $\mathrm{F}_{1}$ & 11.89 & 12.00 & 0.54 & 0.51 & 42.3 & 36.3 & 1.99 & 1.88 & 13.86 & 14.68 \\
\hline & $\mathrm{F}_{2}$ & 12.69 & 12.73 & 0.50 & 0.49 & 28.1 & 24.2 & 1.02 & 0.96 & 15.75 & 16.35 \\
\hline & $\mathrm{F}_{3}$ & 12.94 & 13.09 & 0.48 & 0.46 & 23.7 & 20.7 & 0.81 & 0.68 & 16.23 & 16.54 \\
\hline \multirow[t]{5}{*}{ Average } & $\mathrm{F}_{4}$ & 13.31 & 13.46 & 0.47 & 0.44 & 18.2 & 15.8 & 0.61 & 0.50 & 16.50 & 17.11 \\
\hline & $\mathrm{F}_{5}$ & 12.80 & 12.89 & 0.49 & 0.47 & 29.6 & 25.1 & 1.27 & 1.16 & 15.91 & 16.41 \\
\hline & $\mathrm{F}_{6}$ & 13.16 & 13.33 & 0.46 & 0.45 & 25.4 & 21.8 & 0.90 & 0.75 & 16.63 & 16.69 \\
\hline & $\mathrm{F}_{7}$ & 13.51 & 13.69 & 0.44 & 0.42 & 20.5 & 16.2 & 0.70 & 0.53 & 16.80 & 17.27 \\
\hline & I & 0.073 & 0.188 & NS & NS & NS & NS & NS & NS & 0.288 & 0.291 \\
\hline \multirow[t]{2}{*}{ LSD 0.05} & $\mathrm{~F}$ & 0.166 & 0.142 & NS & NS & 2.93 & 1.99 & 0.093 & 0.072 & 0.184 & 0.258 \\
\hline & $\mathrm{I} \times \mathrm{F}$ & 0.286 & 0.246 & NS & NS & 5.07 & 3.46 & 0.161 & 0.125 & 0.319 & 0.447 \\
\hline
\end{tabular}

$I_{1}, I_{2}$ and $I_{3}$ : Irrigation at 70,50 and $30 \%$ of available water $(A W)$, respectively.

$F_{1}: 100 \%$ mineral $N$

$\mathrm{F}_{2}: 50 \%$ organic $N$ (cattle manure) plus $50 \%$ mineral $N$

$F_{3}: 75 \%$ organic $N$ (cattle manure) plus $25 \%$ mineral $N$

$F_{4}: 100 \%$ organic $N$ (cattle manure)

$\mathbf{F}_{5}: \mathbf{5 0} \%$ organic $\mathbf{N}$ (chicken manure) plus $50 \%$ mineral $\mathbf{N}$

$F_{6}: 75 \%$ organic $N$ (chicken manure) plus $25 \%$ mineral $N$

* At harvest time (June $23^{\text {rd }}$ and June $25^{\text {th }}$ ) in 2012 ad 2013 seasons.

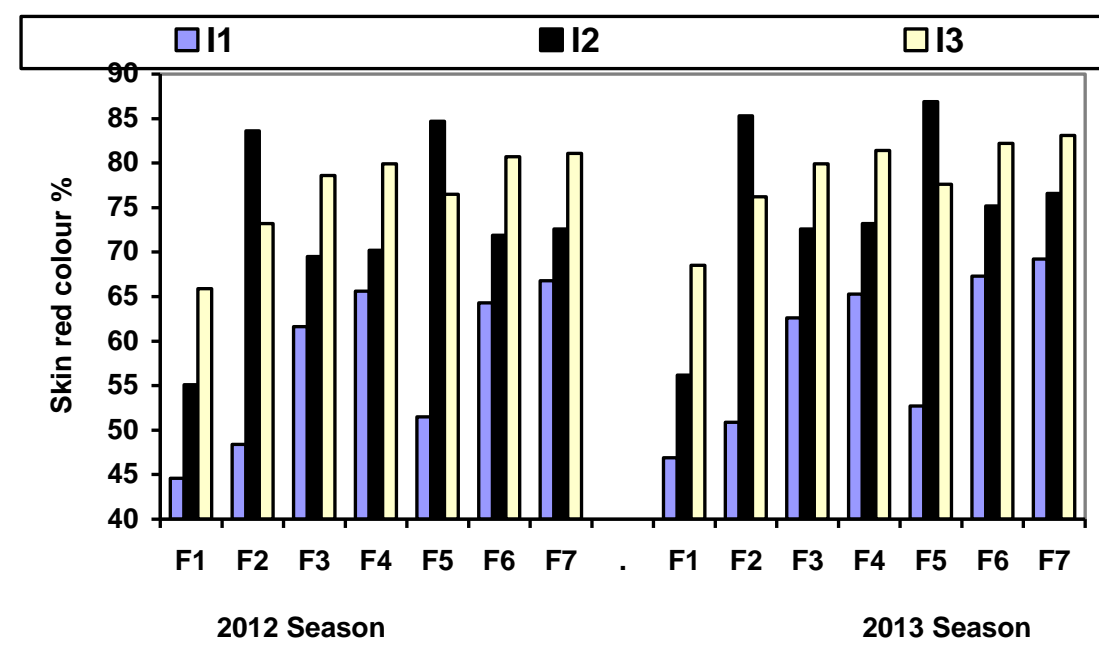

Fig. (1): Skin red colour \% of "Anna" apple fruits as influenced by irrigation regime and organic fertilization during 2012 and 2013 seasons.

$I_{1}, I_{2}$ and $I_{3}$ : Irrigation at 70,50 and $30 \%$ of available water $(A W)$, respectively.

$\mathrm{F}_{1}: \mathbf{1 0 0 \%}$ mineral $\mathrm{N}$

$\mathrm{F}_{2}: \mathbf{5 0 \%}$ organic $\mathrm{N}$ (cattle manure) plus $50 \%$ mineral $N$

$F_{3}: 75 \%$ organic $N$ (cattle manure) plus $25 \%$ mineral $N$

$\mathbf{F}_{5}: \mathbf{5 0 \%}$ organic $\mathbf{N}$ (chicken manure) plus $50 \%$ mineral $N$

$\mathrm{F}_{4}: 100 \%$ organic $\mathrm{N}$ (cattle manure)

$F_{6}: 75 \%$ organic $N$ (chicken manure) plus $25 \%$ mineral $N$

$\mathrm{F}_{7}: \mathbf{1 0 0 \%}$ organic $\mathrm{N}$ (chicken manure) 
Conclusively, irrigated "Anna" apple trees with moderate irrigation rate under soil application with $50 \%$ cattle or chicken manure plus $50 \%$ mineral nitrogen in $\left(\begin{array}{llll}\mathrm{I}_{2} & \mathrm{x} & \mathrm{F}_{2}\end{array}\right)$ and/or $\left(\mathrm{I}_{2} \times \mathrm{F}_{5}\right)$ combination treatments was considered the suitable one. This treatment no only increased productivity of "Anna" apple trees but also improved fruit quality, especially fruit weight, volume and color as well as increasing TSS and reducing nitrate and nitrite content beside saving irrigation water.

\section{Some water relations:}

a.Water consumptive use $(\mathrm{CU})$ :

Data obtained in Table (7) indicated that water consumptive use (CU) of apple trees $\left(\mathrm{m}^{3} / \mathrm{fed}\right)$ was significantly influenced by irrigation regime, organic manure and their interaction in both seasons. It decreased by decreasing irrigation rate. The maximum values of seasonal consumptive use (UC) was obtained with high irrigation level $\mathrm{I}_{1}$ with $(2293.8$ \& 2296.6 $\mathrm{m}^{3}$ /fed/year), while minimum values belonged to deficit irrigation rate with $\left(1650.3 \& 1670.8 \mathrm{~m}^{3} / \mathrm{fed} /\right.$ year $)$ in 2012 and 2013 seasons, respectively. These results are in harmony with those of Abd El-Samad et al. (2006) who found that pear trees which received more frequent irrigation had greater $\mathrm{CU}$ than trees received less frequent irrigation under the same conditions of climatic. Similar results were also obtained by Mikhael and Mady (2007) on apple, El-Abd et al. (2012) and Moursi and Abo El-Enien (2015) on citrus.

Table (7):Water consumptive use (CU), water use efficiency (WUE) and productivity of irrigation water (PIW) for "Anna" apple trees as influenced by irrigation and organic fertilization treatments and their interaction during 2012 and 2013 seasons.

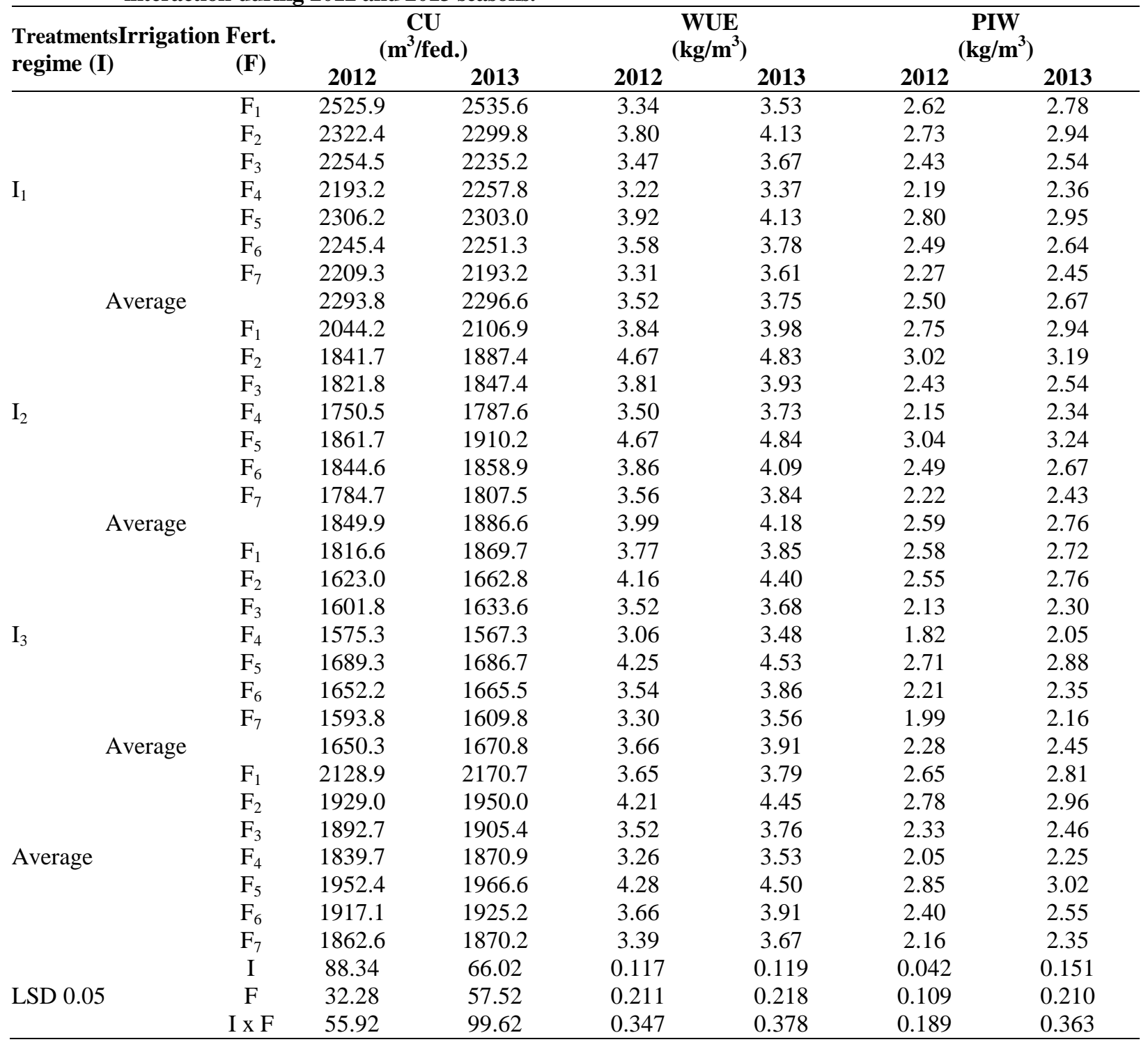

$I_{1}, I_{2}$ and $I_{3}$ : Irrigation at 70,50 and $30 \%$ of available water $(A W)$, respectively.

$\mathrm{F}_{1}: \mathbf{1 0 0 \%}$ mineral $\mathrm{N}$

$\mathrm{F}_{2}: \mathbf{5 0 \%}$ organic $\mathrm{N}$ (cattle manure) plus $50 \%$ mineral $\mathrm{N}$

$F_{3}: 75 \%$ organic $N$ (cattle manure) plus $25 \%$ mineral $N$

$F_{4}: 100 \%$ organic $N$ (cattle manure)

* At harvest time (June $23^{\text {rd }}$ and June $25^{\text {th }}$ ) in 2012 ad 2013 seasons.

$\mathrm{F}_{5}: \mathbf{5 0 \%}$ organic $\mathrm{N}$ (chicken manure) plus $50 \%$ mineral $\mathbf{N}$ $F_{6}: 75 \%$ organic $N$ (chicken manure) plus $25 \%$ mineral $N$ $\mathrm{F}_{7}: \mathbf{1 0 0 \%}$ organic $\mathrm{N}$ (chicken manure) 
With regard to the impact of organic manures, the data exhibited significant decrease by raising the application rate of organic manure. In this respect, trees fertilized with all recommended nitrogen via mineral source $\left(\mathrm{F}_{1}\right)$ consumed the highest values of water consumptive use $\left(2128.9 \& 2170.7 \mathrm{~m}^{3} / \mathrm{fed} /\right.$ year $)$ in $1^{\text {st }}$ and $2^{\text {nd }}$ seasons, respectively, while, trees received $100 \%$ cattle or chicken manure consumed the least values. These findings are in complete agreement with those obtained by Ibrahium and Abd El-Samad (2009) on pomegranate trees. However, the interaction was significant in the two seasons. Trees irrigated at $70 \%$ AW and fertilized by $100 \%$ mineral fertilizer $\left(\mathrm{I}_{1} \times \mathrm{F}_{1}\right)$ (control) recorded the highest $\mathrm{CU}$ values $(2525.9$ \& $2535.6 \mathrm{~m}^{3} / \mathrm{fed} /$ year) in first and second seasons, respectively. Meanwhile the least values came from $\left(\mathrm{I}_{3}\right.$ $\left.\begin{array}{lll}x & F_{4}\end{array}\right)$ and/or $\left(\begin{array}{llll}I_{3} & x & F_{7}\end{array}\right)$ interaction $(1575.3 \& 1567.3$ $\mathrm{m}^{3} /$ fed/year) and $\left(1593.8 \& 1609.8 \mathrm{~m}^{3} / \mathrm{fed} /\right.$ year $)$ in first and second seasons, respectively. Other combination treatments came in-between.

b. Water use efficiency (water productivity) and productivity of irrigation water:

WUE (PI) and PIW values are used to evaluate the effectiveness of irrigation and organic fertilization practices for maximum utilization of water supplies (Table 7).

Water use efficiency (WUE) or water productivity (PI) is a tool for maximizing crop production per unit of consumed water (CU) while, productivity of irrigation water (PIW) is a tool for maximizing crop production per unit of applied water (WA). Tabulated data in Table (7) showed that WUE and PIW of "Anna" apple trees were significantly influenced by irrigation level (I), organic fertilization $(\mathrm{F})$ and their interaction $(\mathrm{I} \times \mathrm{F}$ ) in both seasons. The highest significant values were obtained when trees irrigated at 50\% AW (moderate irrigation) regime followed by those irrigated at $30 \%$ and $70 \% \mathrm{AW}$, respectively in both seasons. Similar findings were achieved by Mikhael and Mady (2007) on apple and El-Abd et al. (2012) and Moursi and Abo ElEnien (2015) on citrus who indicated a gradual decrease in WUE (PI) and PIW value due to increase the amount of applied water.

As for the effect of fertilization treatments, the present data cleared that, application of $50 \%$ cattle or chicken manure $\left(\mathrm{F}_{2} \& \mathrm{~F}_{5}\right)$ for "Anna" apple trees gave the highest significant values of WUE and PIW without significant differences between them compared to using organic (cattle or chicken) manure or mineral fertilizer alone. These results are supported by the conclusion of Ibrahim and Abd El-Samad (2009) who obtained relative increment in water use efficiency by using organic manures to pomegranate trees due to the positive influence of organic manure on saving water use and improving efficiency of water uptake.

As for the interaction, the data revealed that the interaction was significant in the both seasons of study and the highest values of WUE and PIW [(4.67 \& 4.83) and $\left.(4.67 \& 4.84) \mathrm{kg} / \mathrm{m}^{2}\right]$ and $[(3.02 \& 3.19)$ and $(3.04$ $\left.\left.\& 3.24) \mathrm{kg} / \mathrm{m}^{3}\right)\right]$ were obtained by $\left(\mathrm{I}_{2} \times \mathrm{F}_{2}\right)$ and $\left(\mathrm{I}_{2} \times \mathrm{F}_{5}\right)$ in first and second seasons, respectively. Without significant difference between them which considered the best combination treatments for reducing consumptive use (CU) and increasing water use efficiency (WUE) and productivity of irrigation water (PIW).

\section{CONCLUSION}

From the above mentioned results, it could be concluded that irrigation "Anna" apple trees grown on clay soil at $50 \%$ available soil water (2851 $\mathrm{m}^{3} / \mathrm{fed} /$ season) and replacing $50 \%$ of mineral nitrogen fertilizer by cattle or chicken manure through adding $11.11 \mathrm{~kg}$ cattle manure $+600 \mathrm{~g}$ ammonium nitrate/tree/season $\left(\mathrm{I}_{2} \times \mathrm{F}_{2}\right)$ or adding $8.70 \mathrm{~kg}$ chicken manure $+600 \mathrm{~g}$ ammonium nitrate/tree/season $\left(\mathrm{I}_{2} \times \mathrm{F}_{5}\right)$ which considered the superior combination treatment under the condition of this study for increasing fruit yield and improving fruit quality, especially fruit weight, volume, color, TSS and reducing nitrate and nitrite content. Beside, decreasing water consumptive use and increasing water use efficiency and productivity of irrigation water.

\section{REFERENCES}

Abd El-Migeed, M.M.M.; M.M.S. Saleh and E.A.M. Mostafa (2007). The beneficial effect of minimizing mineral nitrogen fertilization on Washington Navel orange trees by using organic and biofertilizers. World J. Agric. Sci., 3(1): 8085.

Abd El-Monem, E.A.A.; M.M.S. Saleh and E.A.M. Mostafa (2008). Minimizing the quantity of mineral nitrogen fertilizers on grapevine by using humic acid, organic and biofertilizers. Res. J. Agric. \& Biological Sci., 4(1): 46-50.

Abd El-Salam, Y.G.; S.A. Nomier and R.A. Al-Ashkar (2009). Using of some bio and organic fertilizers to reduce the rate of mineral $\mathrm{N}$ fertilization and improving orange tree production. Zagazig J. Agric. Res. 36(4): 691-719.

Abd El-Samad, G.A.; M.E. Morsi and T.A. Yehia (2006). Effect of organic fertilization and irrigation levels on water use, growth and productivity of pear trees. Egypt. J. of Appl. Sci., 21(12b): 695-712.

Ahmed, F.F.; A.M.K. Abd El-Aal and A.A.B. Masoud (2012). Attempts for reducing pollution in Ruby seedless grapes by some organic manures enriched with EM. Minufiya J. Agric. Res., 37(3): 611-619.

Ali, M.H.; M.R. Hoque; A.A. Hassan and A. Khair (2007). Effects of deficit irrigation on yield, water productivity and economic return of wheat. Agricultural Water Management, 92(3): 151-161.

AOAC (Association of Official Agriculture Chemists) (1990). Official methods of analysis. $15^{\text {th }} \mathrm{Ed}$. Washington D.C., USA. 
Barakat, M.R..; T.A. Yehia; W.D. Salem and B.M. Sayed (2007). Effect of organic and biofertilization on growth and productivity of peach trees cv. Florida Prince 1-flowering and fruiting characteristics. Egypt. J. of Appl. Sci. 22(6A): 270-282.

Behboudian, M.H.; G.S. Lwes and K.M. Griffiths (1994). The influence of water deficit on water relation, photosynthesis and fruit growth in Asian pear (Pyrus serotina Rehd.). Scientia Horticulture, 60: 94-99.

Black, C.A. (1983). Methods of soil analysis. Part I and II. Amer. Agron. Inc. Publ., Madison, Wisconsin, USA.

Bogatyre, A.N. (2000). What are we do to eat or how to live longer? Pishchevaya Promyshlennost, 78: 3435 .

El-Abd, A.A.; E.A. Moursi and M.A. Gabr (2012). Effect of irrigation water regime on Navel orange yield, fruit quality and some water relations in the North Nile Delta region. J. Plant Production, Mansoura Univ., 3(6): 1049-1061.

El-Gendy, R.W. and W.M. Abd El-Messeih (2002). Water consumption and apple tree productivity as affected by soil water suction and irrigation scheduling. Minufiya J. Agric. Res., 27(2): 391405.

El-Khawaga, A.S. (2011). Partial replacement of mineral $\mathrm{N}$ fertilizer by using humic acid and Spirulina platensis algae biofertilizer in Florida Prince peach orchards. Middle East Journal of Applied Sciences 1(1): 5-10.

El-Sehrawy, O.A.M. (2008). Influence of bio and organic fertilization on growth of "Anna" apple in the reclaimed land. Ph.D. Thesis, Fac. of Agric., Shebin El-Kom Minufiya Univ., Egypt.

El-Sisy, L.M.H. (2000). Assessing the pollution caused by excessive nitrogen fertilization. J. Agric. Sci. Mansour Univ., 25(11): 7297-7313.

El-Wasfy, M.M.M. and M.M.A. Abd El-Rahman (2014). Reducing inorganic $\mathrm{N}$ fertilizer partially in Hayany date palm orchards by using animal and chicken manures. World Rural Observations 6(1): 94-98.

Fallahi, E.; D. Neilsen; G.H. Neilsen; B. Fallahi and B. Shafii (2010). Efficient irrigation for optimum fruit quality and yield of apples. HortScience Vol. 45(11): 1616-1619.

FAO (2013). Food and Agriculture Organization. http://faostat.fao. org.

Fathi, M.A. (1999). Drip irrigation efficiency for pear trees. A- Yield, fruit properties and vegetative growth. J. Agric. Sci. Mansoura Univ., 24(6): 3021-3034.

Gad El-Kareem, M.R. (2009). Response of Swelling and Florida Prince trees to application of some rest-breaking chemicals as well as organic and biofertilization under Sohag conditions. Ph.D. Thesis, Fac. of Agric., Minia Univ., Egypt.
Garhwal, P.C.; P.K. Yadv; B.D. Sharma; R.S. Singh and A.S. Ramniw (2014). Effect of organic manure and nitrogen on growth, yield and quality of Kinnow mandarin in sandy soils of hot arid region. African Journal of Agricultural Research, 9(34): 2638-2647.

Gorge, A.B. and R.J. Nissen (2002). Effect of drought on fruit set, yield and quality of custard apple (Annona spp. hybrid) "African pride" plants. J. Hort. \& Biotech., 77(4): 418-427.

Goring, G.A.L. (1962). Control of nitrification by 2chloro-6 (trichloromethyl) pyrine. Soil Sci. 93: 211-218.

Hallberg, G.R. D.R. Keeriey (1993). Nitrate: Regional Ground-Water Quality via Nostr and Reinhold. Alley, William A. ed., New York, pp. 297-322.

Hanks, R.D. (1983). Yield and water use relationships. Amer. Soc. Agron. 13: 393-411.

Hansen, V.W.; O.W. Israelsen and Q.E. Stringhavm (1979). Irrigation. Principles and Practice, $4^{\text {th }}$ ed. John Wiley and Sons, New York, USA.

Ibrahim, A.M. and G.A. Abd El-Samad (2009). Effect of different irrigation regimes and partial substitution of $\mathrm{N}$-mineral by organic manures on water use, growth and productivity of pomegranate trees. European Journal of Scientific Research, 38(2): 199-218.

Kaya, S.; S. Evren; E. Dasci; M.C. Adiguzel and H. Yilmaz (2010). Effects of different irrigation regiems on vegetative growth, fruit yield and quality of drip-irrigated apricot trees. African J. Biotechnology, 9(36): 5902-5907.

Klute, A. (1986). Methods of Soil Analysis Part 1-2 ed. ASA and SSSA, Madison.

Li, S.H.; J.G. Huguet; P.G. Schoch and P. Orlando (1989). Response of peach trees growth and cropping to soil water deficit at various phonological stages of fruit development. J. Hort. Sci., 64: 541-552.

MALR (2003). Ministry of Agriculture and Land Reclamation. Planting and Productivity of apple in Egypt. Horticultural Institute, ARC, Bulletin, No. 14, (In Arabic)

Mansour, A.E.M.; F.F. Ahmed; A.M.K. Abdel-All and G.P. Clmpoles (2007). Using mineral, organic, slow release and biofertilizers for Anna apple trees in a sandy soil. African Crop Science Conference Proceeding, 8: 265-271.

Masoud, A.A.B. (2012). Effect of organic and bionitrogen fertilization on growth, nutrient status and fruiting of Flame seedless and Ruby seedless grapevines. Res. J. Agric.\& Biological Sci., 8(2): 83-91.

Michael, A.M. (1978). Irrigation theory and practice. Vikus Publishing House, PVTLTD, New Delhi, India.

Mikhael , G.B. and A.A. Mady (2007). Effect of some drip irrigation and mulching treatments on: II. Yield, fruit quality and water use efficiency of "Anna" apple trees grown in new reclaimed soils. Minufiya J. Agric. Res., 32(4): 1175-1191. 
Mikhael, G.B.Y.; M.A. Aziz and W.M. Abd El-Messeih (2010). Effect of some flood irrigation and potassium fertilization treatments on vegetative growth, yield and fruit quality of "Dessert Red" peach trees grown in clay soil. J. of Plant Production 1(4): 599-620.

Moharam, F.A. and E.M.A. Zaen El-Deen (2011). Effect of partial substitution of mineral fertilizers with organic fertilizers on peach production under supplemental irrigation in North Sinai. Res. J. Agric. \& Biological Sci., 7(5): 434-442.

Moursi, E.A. and M.M. Abo El-Enien (2015). Studying behavior of Navel orange trees under different irrigation treatments in the north middle Nile delta. Annals of Agric. Sci., Moshtohor, 53(3): 415-424.

Mpelasoka, B.S.; M.H. Behboudian and T.M. Mills (2001). Water relations photosynthesis growth, yield and fruit size of "Braeburn" apple response to deficit irrigation and crop load. J. Hort. \& Biotech., 76(2): 150-156.

Naor, A.; I. Klein; I. Doron; Y. Gal; Z. Ben-David and B. Braudo (1997). Irrigation and crop load interaction in relation to apple yield and fruit size distribution. J. Amer. Soc. Hort. Sci., 122(3): 411 414.

Nijjar, G.S. (1985). Nutrition of fruit trees. Mrs Msha Raj Kumar for Kalyani Publishes. New Delhi, India, pp. 10-52.

Ranganna, S. (1979). Manual analysis of fruit and vegetable products. New Delhi, India, pp. 88-91.

Sahrawat, K.L. (1979). Nitrogen losses in rice soils. Fert. News 24: 38-48.

Salama, M.I.; A.F.; A.F. El-Samak; A.A. El-Morsy and K.M.M. Aly (2012). The beneficial effects of minimizing mineral nitrogen fertilization on sewy date palm trees by using organic and biofertilizers. J. Plant Production, Mansoura Univ., 3(9): 2411-2424.
Seleem, B.M.; A.M. Telep (2008). Effect of organic and biofertilizers as a partial substitute for inorganic nitrogen in superior grapevines. Minia J. Agric. Res. \& Develop. 28(1): 23-35.

Sen, N.P. and B. Donaldson (1978). Improved colormetric method for determining nitrate and nitrite. Food J. Assoc. Anal. Chem., 16: 13891395.

Shaheen, MA.; S.M. Abd El-Wahab; F.M. El-Morsy and A.S.S. Ahmed (2013). Effect of organic and biofertilization as a partial substitute for NPK mineral fertilizer on vegetative growth, leaf mineral content, yield and fruit quality of superior grapevine. J. Hort. Sci. \& Ornamental Plants 5(3): 151-159.

Snedecor, G.W. and W.G. Cochran (1990). Statistical Methods. $7^{\text {th }}$ Ed., Iowa State Univ., USA, p. 593.

Wang, Y.; S. Travels; M.G. Bertelsen; K. ThorupKristensen; K.K. Petersen and F. Liu (2014). Effect of root pruning and irrigation regimes on pear tree: growth, yield and yield components. Hort. Sci. (Prague), Vol. 41(1): 34-43.

Wassel, A.M.; A.M.K. Abdelaal; A.M. Gowda and M.H. Abdel Aziz (2015). Response of Kadotta fig using some organic manures enriched with EM as a partial substitution of mineral $\mathrm{N}$ fertilizer. World Rural Observation, 7(2): 22-29.

Zayan, M.A. and E. Morsy (1989). Studied on rest period of "Anna" apple buds under the agroclimatic conditions in North Delta. J. Agric. Res. Tanta Univ., 15(1): 54-64.

Zuoping, Z.; Y. Sha; L. Fen; J. Puhui; W. Xiaoying and T. Yan'an (2014). Effects of chemical fertilizer combined with organic manure on Fuji apple quality, yield and soil fertility in apple orchard on Loess Plaleaa of China. Int. J. Agric. \& Biol. Eng., 7(2): 45-55. 
Mikhael, G.B.Y. and Manal A. Aziz

تأثير إحلال الأسمدة العضوية محل النيتروجين المعدنى تحت معدلات مختلفة من الرى على:

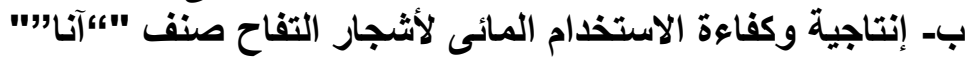

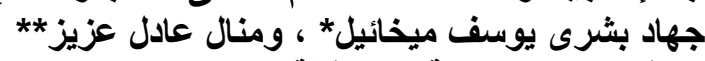

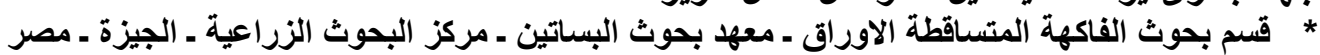

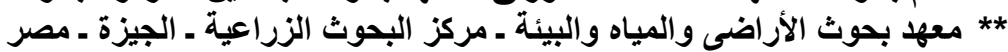

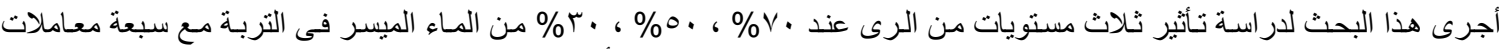

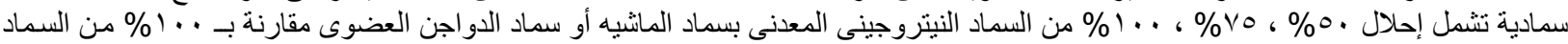

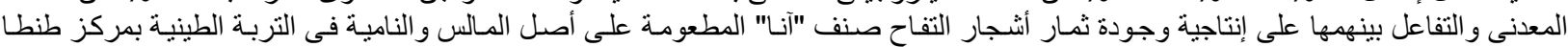

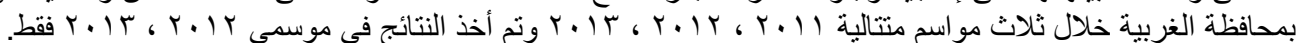
ويمكن تلخيص النتائج المتحصل علئ اليها كما يلى:

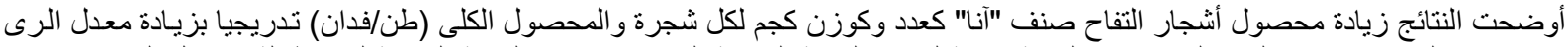

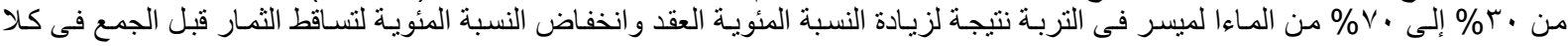
الموسمين.

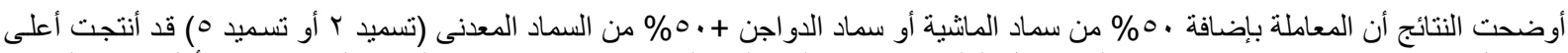

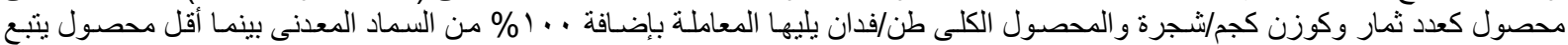

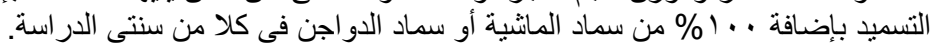

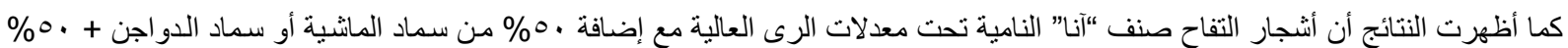

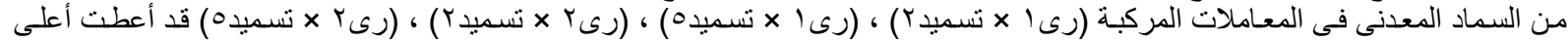

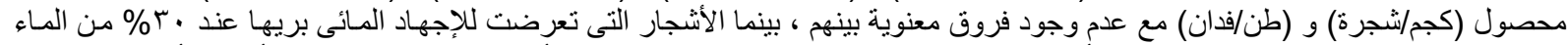

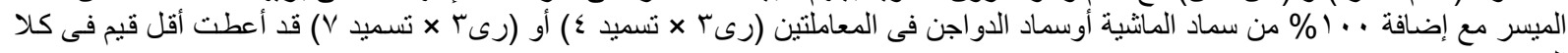
الموسمين.

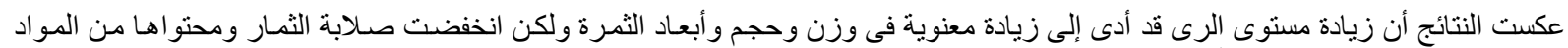

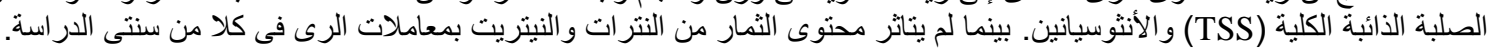

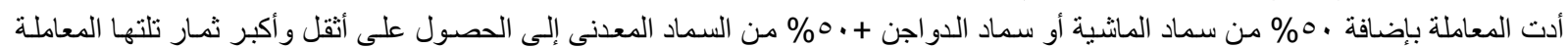

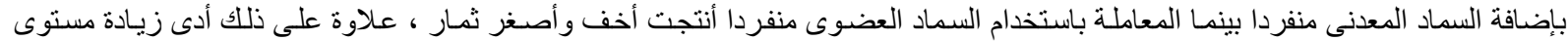

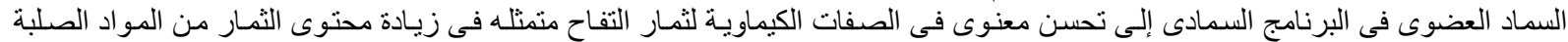

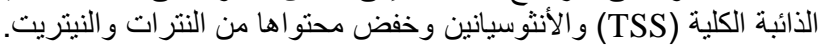

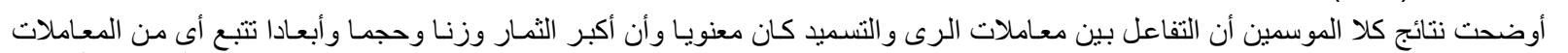

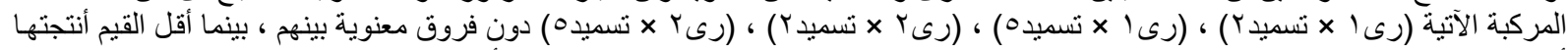

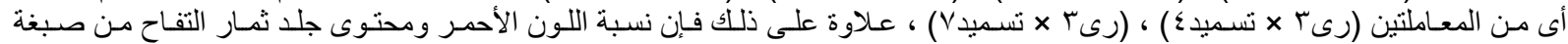

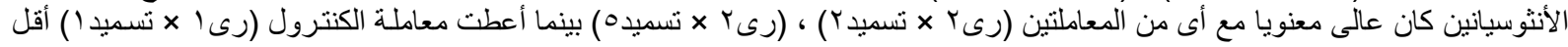

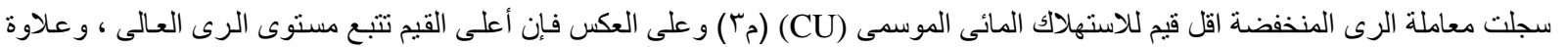

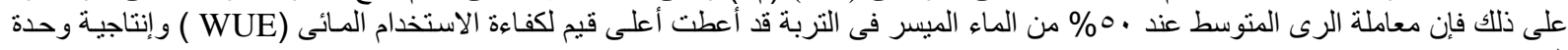

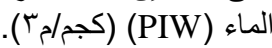

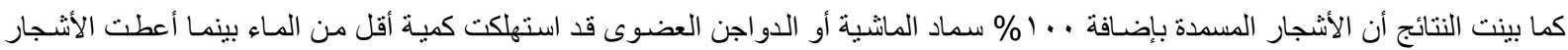

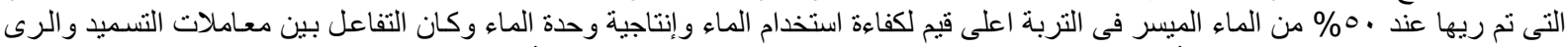

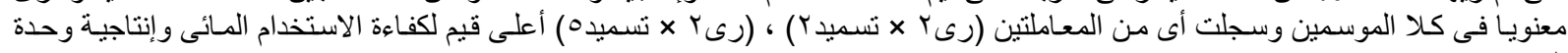

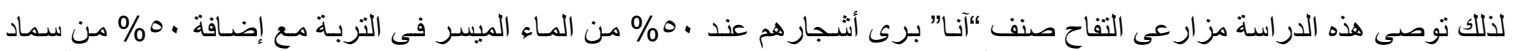

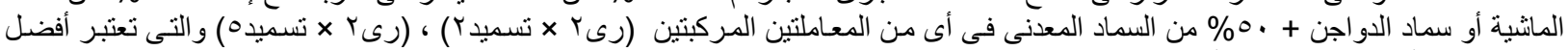

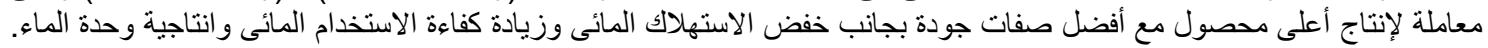

